\title{
Integration of core, well logging and 2D seismic data to improve a reservoir rock model: a case study of gas accumulation in the NE Polish Carpathian Foredeep
}

\author{
HA QUANG Man ${ }^{1}$ and Jadwiga JARZYNA ${ }^{2, *}$ \\ 1 Hanoi University of Mining and Geology, Faculty of Petroleum, 8th Floor, C12 Building, Dongngac, Tuliem, Hanoi, Vietnam \\ 2 AGH University of Science and Technology, Faculty of Geology Geophysics and Environmental Protection, al. \\ Mickiewicza 30, 30-059 Kraków, Poland
}

Ha Quang M. and Jarzyna J. (2013) Integration of core, well logging and 2D seismic data to improve a reservoir rock model: a case study of gas accumulation in the NE Polish Carpathian Foredeep. Geological Quarterly, 57 (2): 289-306, doi: 10.7306/gq.1091

\begin{abstract}
Geological models play a crucial role in the description and simulation of fluid flow of both hydrocarbon- and water-bearing strata. Methodology, based on the hydraulic flow unit build on the basis of core plug data combined with rock types determined from logs and 3D seismic cubes generated on the basis of 2D seismic sections is presented. It works as a possible exploration tool for the Miocene gas accumulations in the Carpathian Foredeep of Poland. Deterministic and stochastic, geostatistical methods were used to construct a static reservoir model from 2D seismic sections, lithological data and hydraulic flow unit data. A pseudo-3D seismic volume was generated from all of the 2D seismic data available, in order to aid the modelling of hydraulic flow units. This approach is applicable to other reservoirs, where the availability of seismic data is limited. This study demonstrates that even without 3D seismic data and with limited well log data, the proposed hydraulic flow unit approach can be successfully applied to reservoir modelling through the integration of diverse data sets for a wide range of scales.
\end{abstract}

Key words: hydraulic flow units, reservoir static modelling, porosity, permeability, well logging, 2D seismics.

\section{INTRODUCTION}

During decades of petroleum exploration in the Carpathian Foredeep, various methodologies have been applied in seismic and well log interpretation (Karnkowski, 1999; Myśliwiec, 2004b; Pietsch et al., 2007; Krzywiec et al., 2008). In the majority of these studies well logging results were used as a basis for the depth calibration of seismic interpretation and the recognition of petrophysical parameters. Porosity, permeability and water saturation have always been the most important properties for engineers, for making decisions about the reservoirs to be developed (Bała, 2011). Interpretations of the depositional environments and facies distribution have been obtained from seismic imaging and well logging (Porębski, 1996; Myśliwiec et al., 2004; Krzywiec et al., 2005, 2008; Myśliwiec, 2006a, b).

The present study examines aspects of reservoir characterization where the availability of geological and geophysical data is limited. The aim is to integrate data from core plugs,

* Corresponding author: jarzyna@agh.edu.pl Received: October 18, 2012; accepted: January 25, 2013; first published online: May 14, 2013 wireline logs and 2D seismic profiles in order to generate a reliable geological model, which can be used for dynamic simulation of media flow in pore space. It is also shown how mathematical modelling, geostatistics and neural networks can help in characterization of geological objects, especially through the application of specialized software. It is also important to point out that the hydraulic flow unit approach can be useful at various scales, from the micro-scale of core plugs, the mesoscale of well logs, and the macro-scale of seismic data in dynamic data simulation.

The computer modelling has already been applied for 3D presentation of petrophysical properties variability (for instance Papiernik et al., 2010), while integrated analyses of parameters originated from lab measurements and log data have also already been used in the analysis of hydrocarbon-bearing strata (for instance Mohammadlou and Mork, 2010) but the case study presented is unique because it is possible to expand to the methodology to other gas fields in the Carpathian Foredeep and other gas fields suffering from lack of complete seismic and well logging data. The methodology developed is designed to be reliable and cost-effective for reservoir characterization in situations of limited data, especially where 3D seismic data are lacking. The workflow used throughout this study (Fig. 1) illustrates a practical approach to handling sparse data for a gas reservoir characterization in a deltaic setting. 


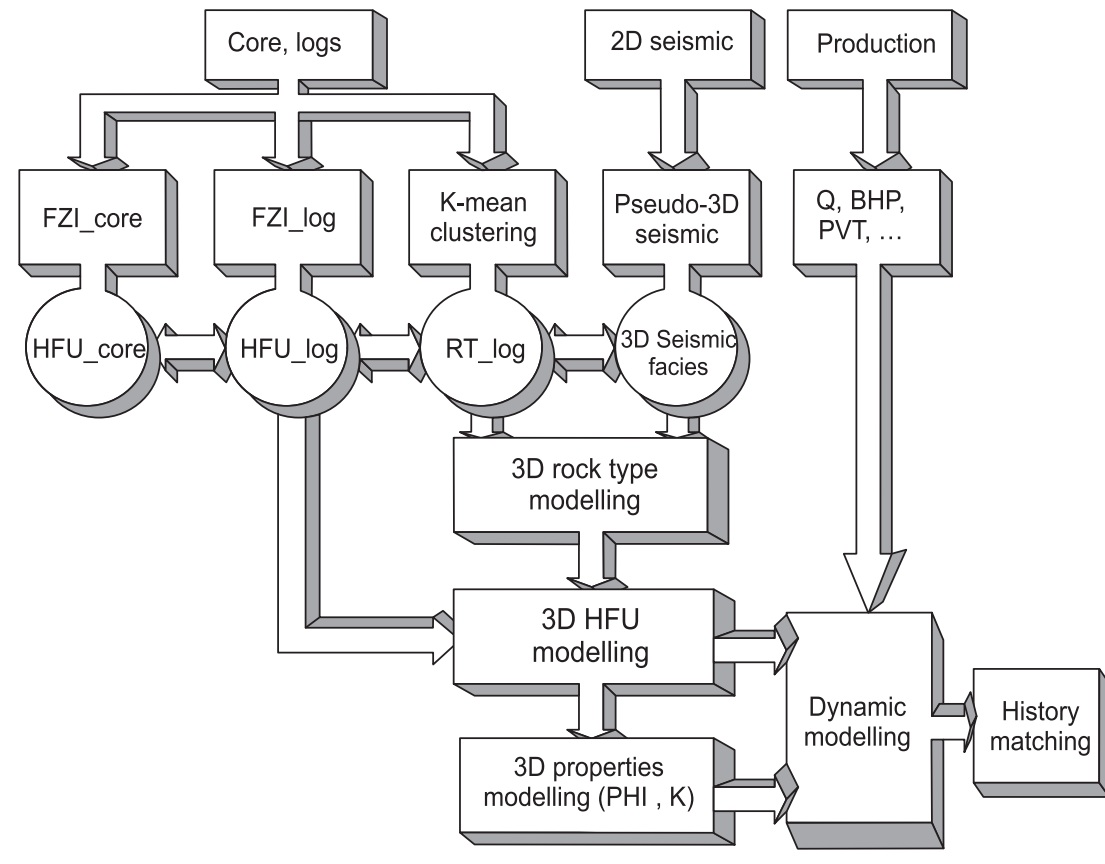

Fig. 1. Workflow for the integration of static and dynamic models on the basis of core data, wireline logs and 2D seismic data

BHP - Bottom Hole Pressure, FZI_core - Flow Zone Indicator calculated from core data, FZI_log - Flow Zone Indicator calculated from logs, HFU_core - Hydraulic Flow Unit calculated from core data $=\mathrm{HU}, \mathrm{HFU}$ log - Hydraulic Flow Unit calculated from logs, $\mathrm{K}-$ permeability, Q - volume of gas, PVT - pressure, volume, temperature data measured during production of hydrocarbons, $\mathrm{PHI}$ - total porosity, RT_log - rock type determined from logs shelf settings, deltaic deposits, and submarine fans (Myśliwiec, 2004a, b, 2006a, b). In the eastern part of the Z Gas Field, the type of traps are mainly structural-stratigraphic and the reservoirs are sandstones. In places, gas also occurs in the mudstone-claystone associations (Krzywiec et al., 2008). However, the majority of the gas accumulations are in the shaly sandstones of deltaic deposits. Variations in lithology and vertical cyclicity are observed as differences in gamma-ray (GR) signature. Reservoir rocks are observed in the upper parts of the strata, identified as the uppermost parts of deltaic accumulations sealed by estuarine deposits.

In the study area, in the most proximal, deltaic deposits, the sandstones include lithic wackes and subarkosic wackes (Śmist, 2003); in the more distal strata fine-grained, well-sorted arenites are observed. Quartz is the most abundant mineral (up to $80 \%$ by volume). The second main component, in terms of percentage by volume, comprises limestone, silicates and shales. The most frequently occurring cement in the sandstones and mudstones comprises clay and calcite. The typical porosity of the study deposits is between 15 and $30 \%$. Where the volume of the calcite cement increases to ten or more percent, the porosity decreases to $3-4 \%$. Beds of the more strongly indurated sandstone occur in all of the sedimentary environments recognized, but most were found in the more distal parts of the submarine fans (Śmist, 2003; Bosak, 2007).

The Sarmatian deposits show evidence of compaction, but a clear influence of this process on porosity and permeability was observable only at depths of more than 900-1000 m. Primary porosity predominates and only a few percent of porosity is of secondary origin, resulting from the dissolution of minerals and bioclasts. Accumulations of kaolinite contribute to decrease of fluid flow in these strata (Śmist, 2003). The mineral composition and sedimentary conditions controlling the thin-bedded structure of the Sarmatian sandy-shaly strata are the source of difficulty in the understanding of porosity-permeability relationships and seismic facies distribution in the reservoir rocks.

\section{DATA SET}

\section{CORE AND WELL LOG DATA}

sion avoided compressional deformation (Krzywiec, 2006). In this area faults cross-cut both the Miocene strata and the underlying basement rocks (Fig. 2).

The Miocene succession of the Carpathian Foredeep has been divided into the Lower Badenian sub-evaporitic series, the Middle Badenian evaporites, and the Upper Badenian and Sarmatian supra-evaporitic units. In this study, only the Sarmatian succession was considered.

The Sarmatian formation was selected for study, because it hosts dozens of gas accumulations that have been discovered during intensive hydrocarbon prospecting in the Polish Carpathians and the Polish part of the Carpathian Foredeep (Karnkowski, 1999). Gas accumulations in the Z Gas Field (18 gas horizons in the eastern part, 10 in the central part, and 3 in the western part) are associated with sediments formed in open-
Core and well log data were available from 10 wells located in the Z Gas Field (Fig. 2). Laboratory core measurements, including effective porosity $(\Phi e)$ and absolute permeability $(K)$, were available from depths between $478 \mathrm{~m}$ (Z-72 well) and $1175 \mathrm{~m}$ (Z-76 well), corresponding to the Sarmatian succession. For the analysis a total number of 570 core samples of the deltaic sequence from depths of between 500 and 900 m was selected to make the data set more consistent.

The well log data set included spontaneous potential log (SP), GR, various resistivity logs (EN16 short normal, EN64 long normal, EL14 short lateral and EL28 long lateral), neutron porosity logs (NPHI), and sonic logs (DT). 


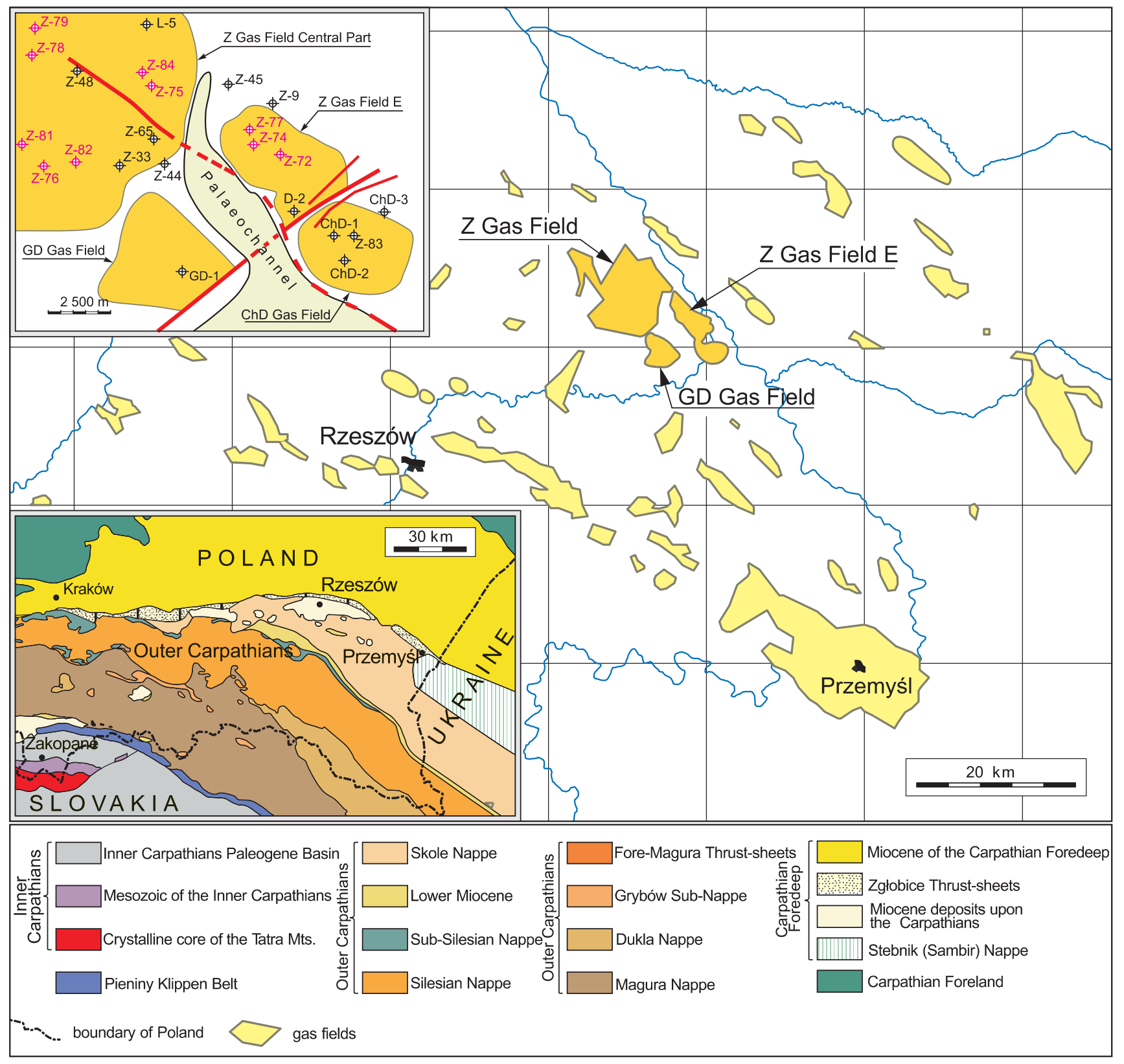

Fig. 2. Location map of the $Z$ Gas Field

Inset map shows the distribution of wells from which cores were taken for laboratory studies (in red), marked tectonic elements; modified from Myśliwiec (2006a) and Oszczypko (1998, 2006)

To enable proper depth matching between core data and the well logs, samples were taken from continuously cored sections to achieve good correlation between the values measured in the laboratory (PHI_core - porosity from core samples) and those determined from the well log (NPHI; Fig. 3). Additionally, the gamma-ray log was used as an indicator of lithology to facilitate the adjustment of the laboratory data to the well log results. The core data were calibrated against the depth scale, since plugs cut from the cores for laboratory measurements deliver information only from a small part of the rock formation. Depth shifts in the intervals compared were not constant, but were regulated by two factors considered together - the similarity in value of the parameters and the sequence of the parameters available from well logs: apparent resistivity (EN16, EN64, EL14 and EL26 logs), GR, NPHI and DT. The correlation coefficients $(R)$ were calculated for the NPHI (log data) and PHI (core data) and pro- vided a measure of the accuracy in depth matching; after depth matching, the correlation coefficient increased from 0.11 to 0.87 (Fig. 3). Additionally, the constant slopes of regression lines in selected sections with depth matching reflected correspondence between NPHI and the PHI. Therefore, depth matching was performed for all of the wells used in the study.

\section{SEISMIC DATA}

A total of $252 \mathrm{D}$ seismic lines were used in the study (Fig. 4). The seismic data were acquired by Geofizyka Kraków Ltd. The majority of the seismic lines was recorded in 2002 (Geofizyka Kraków, 2002). The oldest data is from 1989 (23A-2-89k), one is from $1991(27-2-91 \mathrm{k})$ and several are from 2000 (1-5-20k, 2-5-20k, 3-5-20k). The seismic data were processed using 

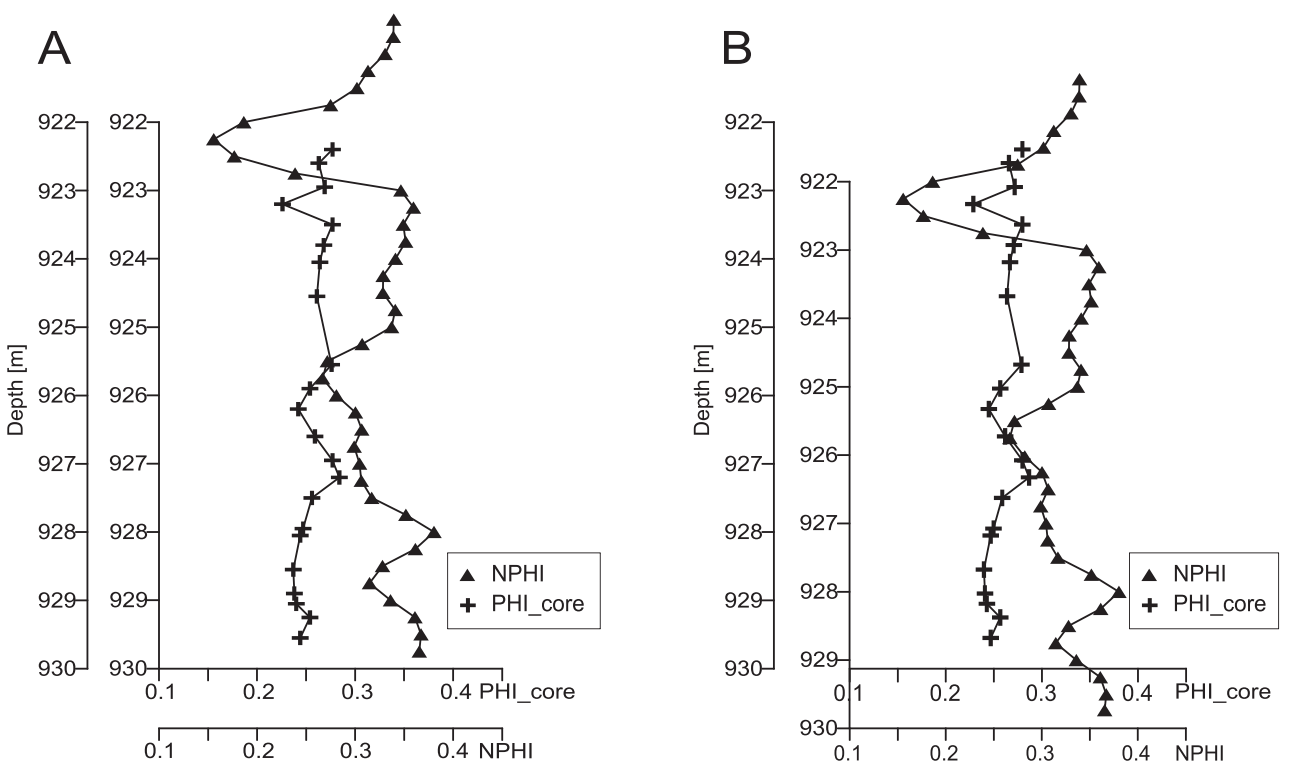

C
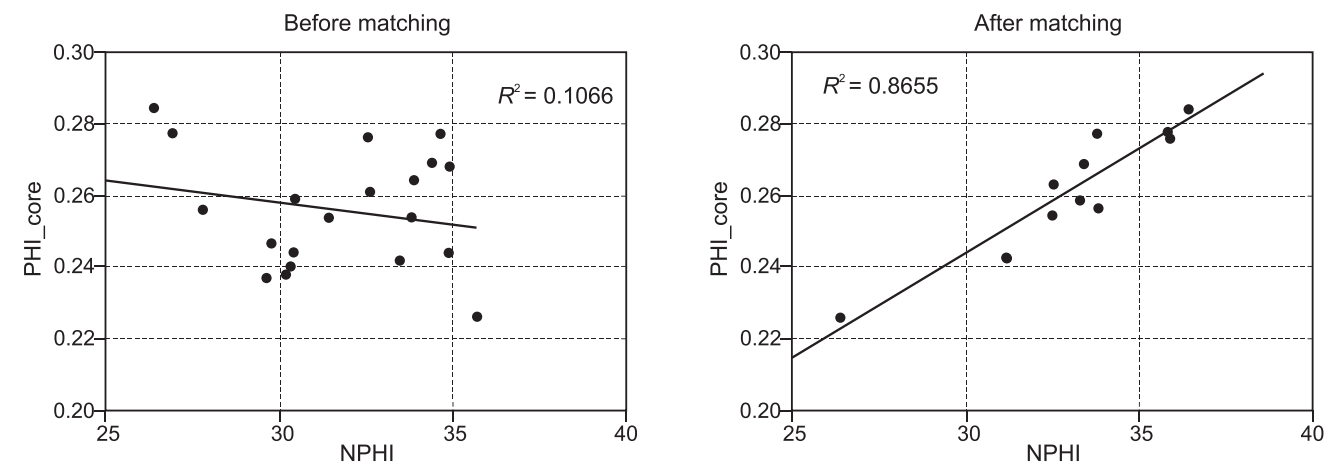

Fig. 3. Two approaches for depth matching between the core and log data in well Z-76

Crosses: laboratory porosity (PHI_core) sampled irregularly; continuous curves with triangles: NPHI, sampled regularly at every $0.2 \overline{5} \mathrm{~m}$; the two horizontal scales of porosity and two vertical scales of depth relate to the matched data sets; $R$ - regression coefficients

standard procedures for trace balance, correction of amplitude anomalies, static and kinematic corrections, velocity analysis, FK filtration, muting, coherent stacking, DMO stacking, RMS gain, frequency filtration, harmonizer deconvolution, FX migration, final RMS gain, and programmed gain.

At the first stage, the mis-ties between all lines were corrected. A simple, but effective algorithm, based upon weighting value assignments with a variance criterion, was used. Mis-tie values were assumed to be random variables. After correction, the mis-ties were reduced to a minimum (0-2 ms) after the error adjustment. After application of the algorithm, a weighting factor was defined for selected reference lines. These lines were first well-adjusted to the well logging data using check-shots and sonic logs. In the next step, a weighting factor was applied to other lines.

\section{METHODOLOGY}

The $Z$ Gas Field was selected for testing the proposed methodology from among other similar Miocene gas accumulations in the Carpathian Foredeep because of the large amount of geological and geophysical data and the good understanding of structural and depositional conditions, as well as because of the petrological and petrophysical properties of the rocks (Karnkowski, 1999; Myśliwiec, 2004a, b, 2006a, b). In the present study, different sources of information were used: geological information, core descriptions, results of laboratory measurements of porosity and permeability and carbonate content, mineralogical descriptions, well logging data especially dipmeter interpretation and the elements of seismic structural interpretation (Bosak, 2007). A study of all geological information revealed the complexity of the structure of the Sarmatian succession. Laboratory data for ten wells were used and data were selected for the deltaic sequence from depths in the range of about 500-900 m. The depth selection limited the data but made it more coherent and uniform.

\section{HYDRAULIC FLOW UNITS}

The hydraulic flow unit (HU) concept provided a method for classifying rock associations and predicting the flow properties, based on both geological parameters and the physics of flow at the pore scale. Amaefule et al. (1993) suggested that the hydraulic quality of a rock is controlled by pore geometry. More recently, the concept of the HU has become an important tool for describing a reservoir in terms of its flow zones (Prasad, 2000; Corbett et al., 2003). Ebanks (1987) defined a HU as “...a 


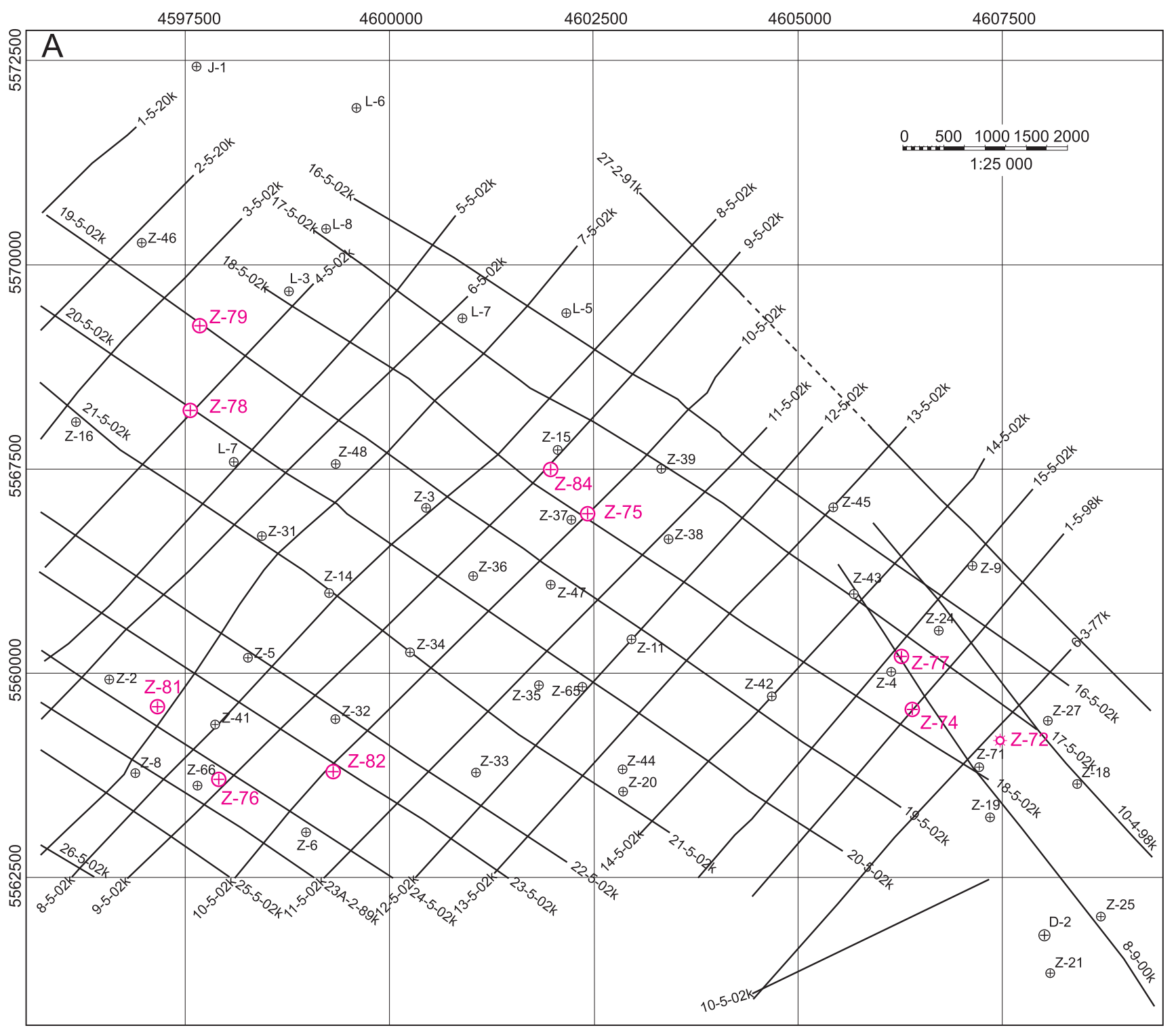

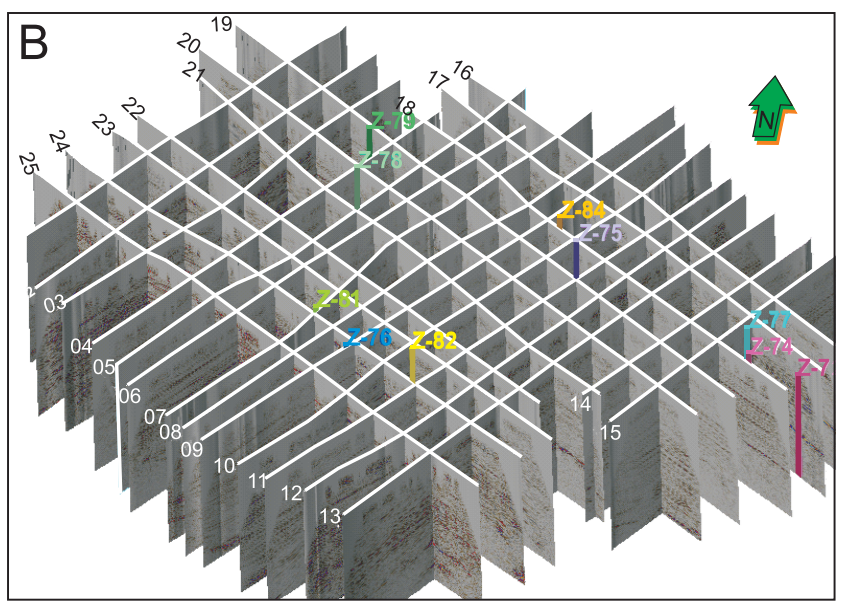

mappable part of a reservoir, within which the geological and petrophysical properties that affect fluid flow were internally consistent and predictably different from the properties of other reservoir volumes". In the framework of that definition, an $\mathrm{HU}$ is represented as a recognizable section on wireline logs and composes a correlative and mappable unit at the inter-well scale. The most important feature of the HU selected was communication with other hydraulic units.
Fig. 4A - location of seismic lines and wells in the study area; names of the seismic profiles are included; B - location of 25 lines 2D seismic lines and 10 wells in 3D image, numbers have been adjusted to seismic lines by the authors

The concept of the hydraulic flow unit combines porosity and permeability. However, permeability depends not only on porosity, but also on pore space geometry, grain size distribution, specific surface area of pore space, tortuosity, fluid saturation and other properties. The Kozeny-Carman equation [1] is the most appropriate formula for the calculation of permeability that includes the above parameters (Kozeny, 1927; Carman, 1937). However, this equation is difficult to apply from parame- 
ters which are either unknown or difficult to calculate, namely specific surface area of pore space $\left(S_{g r}\right)$ and tortuosity $(\tau)$.

$$
K=\frac{1}{2 \tau^{2} S_{g r}^{2}} \frac{\Phi_{e}^{3}}{\left(1-\Phi_{e}\right)^{2}}
$$

where: $K$ - permeability; $\Phi_{\mathrm{e}}$ - effective porosity.

Amaefule et al. (1993) reorganized equation [1] in the form presented as formula [2]:

$$
F Z I=0.0314 \sqrt{K / \Phi_{e}} \cdot \frac{1-\Phi_{e}}{\Phi_{e}}
$$

which means that the Flow Zone Indicator $(F Z I)$ is defined only on the basis of porosity and permeability. On the basis of equation [2], the relationship between permeability and porosity could be plotted on a log-log plot as a straight line, with the slope dependent on FZI. Such a representation of laboratory data is useful because unit slope lines could be easily distinguished (Jarzyna and Ha Quang, 2009). In equation [2], FZI was correlated to wireline log responses for known core permeability and porosity data. Thus, FZI was the parameter which had an assigned numerical value and was the basis for defining the $\mathrm{HU}$ as a part of a reservoir which has determined permeability and porosity enabling fluid flow in pore space (Table 1).

\section{GEOLOGICAL MODEL AND RESERVOIR PROPERTIES MODEL}

Several new methods have been presented in the literature as regards to the use of 3D seismic data to improve facies modelling. However, only a few papers have discussed the application of 2D seismic data for the determination of facies distribution. Shuguang et al. (1999) presented a conditional 3D lithofacies simulation with $2 \mathrm{D}$ seismic data by integrating $2 \mathrm{D}$ vertically averaged lithofacies proportions into 3D lithofacies distributions. 2D seismic information was used in the cokriging of the $2 \mathrm{D}$ average lithofacies proportions. The results showed that even with limited well data, the input of vertical lithofacies proportions (which carry the seismic information) were represented quasi-exactly.

In the study presented, facies modelling based only on log data led to unsatisfactory results. Accordingly, the integrated well log information and the $2 \mathrm{D}$ seismic data were included to improve the modelling. The results were used as input for 3D $\mathrm{HU}$ modelling and 3D property modelling. The main steps used in this study are shown in the workflow (Fig. 5).

The workflow starts from 2D seismics (the lowest rectangle at the left hand side). Next, following the arrows, one can trace the procedures applied to $2 \mathrm{D}$ seismic data, i.e. mis-tie correction, horizon picking and others, up to amplitude modelling. After using the SGS statistical procedure, the AMPLITUDE MODEL is completed. Next, the 3D seismic cube (" $3 D$ Seismics") is constructed on the basis of previous data. Now, following the arrows the procedures applied to the seismic data can be tracked. First, selected attributes are calculated, then seismic facies are determined, using the Unsupervised Neural Network. To improve the seismic origin facies, additional data from well logging are included. Procedures applied to well logging are presented on the right hand side of the workflow and those applied to core data are listed in the part on the far right. The rock types are determined on the basis of well logs, using the $\mathrm{K}$-mean procedure, and are incorporated into seismic facies modelling by the statistical procedure SIS. Three-dimensional reservoir modelling is a broad field of expertise, in which geostatistics is one of several key components. The aim of 3D modelling is to provide one or more alternative $3 D$ numerical models to represent those geological, geophysical, and reservoir engineering aspects of the rock succession that help in achievement of the study goal. These numerical models are used to estimate the main reservoir parameters, for example, original oil in place, to predict production performance and to provide uncertainty statements, when needed (Caers, 2005).

Bohling (2005) explained the use SGS and SIS in stochastic simulation. In this study, SGS method was used for conversion of 2D seismic results to a pseudo-3D seismic cube, i.e. to interpolate seismic amplitudes and times in three directions, and for estimating continuous variables such as porosity from logs. However, SIS method was applied for determining categorical variables like rock type. Stochastic classification, using SIS, was also applied to obtain seismic facies distribution results in agreement with the well data at each well location, and improved the horizontal resolution, related to the uneven, spatial distribution of the wells. As a result, the Facies_UNN_SIS are determined and used in the next step, which is hydraulic unit modelling. To get an appropriate HU_MODEL, the well log data are combined with core data in the form of the HU_log. The hydraulic unit model and porosity model (PHI_MODEL) are combined to obtain the permeability model (K_M MODEL). All of the procedures included in the workflow in Figure 5 are described below.

Table 1

Simple statistics of K_core, $\Phi$, FZI and the determination coefficients $\left(R^{2}\right)$ for the permeability calculated

\begin{tabular}{|c|c|c|c|c|c|c|c|c|c|c|c|}
\hline \multirow{2}{*}{$\mathrm{HU}$} & \multirow{2}{*}{$\begin{array}{l}\text { No of data } \\
\text { in } \mathrm{HU}\end{array}$} & \multicolumn{3}{|c|}{ K_core [mD] } & \multicolumn{3}{|c|}{$\Phi$} & \multicolumn{3}{|c|}{ FZI } & \multirow{2}{*}{${ }^{*} R^{2}$} \\
\hline & & $\min$ & mean & $\max$ & $\min$ & mean & $\max$ & $\min$ & mean & $\max$ & \\
\hline HU1 & 28 & 0.02 & 0.72 & 2.82 & 0.070 & 0.160 & 0.233 & 0.095 & 0.283 & 0.400 & 0.728 \\
\hline $\mathrm{HU} 2$ & 58 & 0.17 & 9.15 & 24.33 & 0.078 & 0.210 & 0.251 & 0.466 & 0.734 & 0.791 & 0.888 \\
\hline HU3 & 89 & 9.78 & 50.75 & 120.04 & 0.150 & 0.240 & 0.292 & 0.977 & 1.379 & 0.687 & 0.645 \\
\hline $\mathrm{HU} 4$ & 117 & 40.47 & 144.72 & 358.55 & 0.203 & 0.257 & 0.315 & 1.733 & 2.100 & 2.563 & 0.743 \\
\hline HU5 & 214 & 79.79 & 445.77 & 1461.70 & 0.189 & 0.260 & 0.320 & 2.587 & 3.510 & 4.512 & 0.603 \\
\hline HU6 & 64 & 430.07 & 1458.96 & 3631.10 & 0.229 & 0.270 & 0.306 & 4.555 & 5.850 & 8.833 & 0.411 \\
\hline All & & & & & & & & & & & 0.970 \\
\hline
\end{tabular}
from the FZI_mean (K_pre) in 6 hydraulic units

* - determination coefficient for relationship of K_FZI_mean vs. K_core; K_pre - predicted permeability; for other explanations see the text 


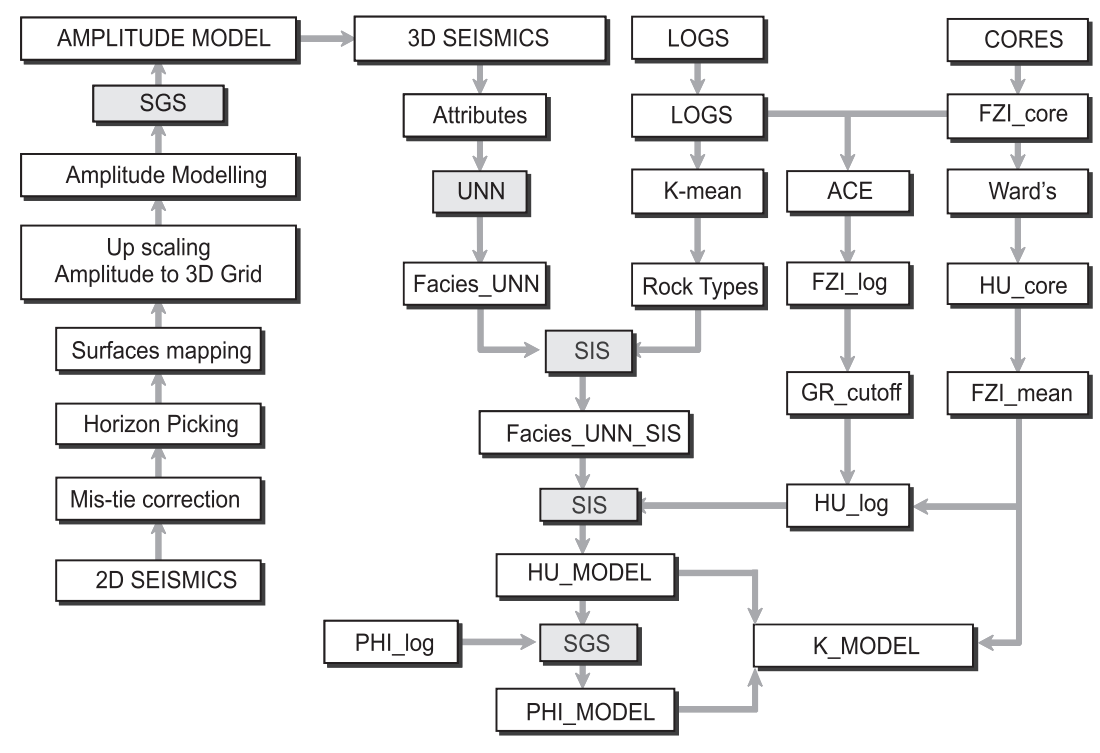

Fig. 5. Workflow for reservoir modelling used in this study

SGS - Sequential Gaussian Simulation; SIS - Sequential Indicator Simulation; UNN Unsupervised Neural Network; ACE - Alternating Conditional Expectation; for other explanations see the text and Figure 1

\section{INTEGRATION OF CORE AND WELL LOG DATA}

\section{CLASSIFICATION OF HYDRAULIC \\ FLOW UNITS FROM CORE DATA}

Several techniques have been proposed for the recognition of hydraulic flow units, on the basis of the identification of rock types and the analysis of porosity-permeability plots (Kolodziej, 1980; Gunter et al., 1997; Corbett et al., 2003). In our hydraulic units were recognized on the basis of FZI (Jarzyna and $\mathrm{Ha}$ Quang, 2009). Each HU was associated with a particular FZI value, but units typically exhibited a variation around each mean $\mathrm{FZI}$, caused by random measurement errors in the core analysis. Multiple hydraulic unit data created difficulties for the identification of each mean FZl and corresponding HU. The following cluster analysis techniques were applied to break down the overall FZI distribution into its constituent elements: use of histograms, the Ward clustering algorithm and probability plots.

Histogram: The FZI distribution was treated as a superposition of multiple log-normal distributions and a histogram of FZI (with the log scale on the $\mathrm{x}$-axis) showed 6 normal distributions for 6 hydraulic units. The clusters were separated and the histogram delineated the $\mathrm{HUs}$ and provided their corresponding FZI values (Fig. 6A). However, the cluster classification was not obvious, since significant overlap was observed. Mean FZI values characteristic for each $\mathrm{HU}$ were determined on the basis of plots of $\mathrm{RQI}=\sqrt{K / \Phi_{e}}$ vs $\frac{1-\Phi_{e}}{\Phi_{e}}$ (Fig. 6B).

where: RQI - reservoir quality index.

Ward clustering algorithm: according to the Ward algorithm theory, in a hierarchical cluster analysis each cluster attains a minimum spread around its mean value, while having maximum separation from other clusters (Ward, 1963). Three black dashed lines and a red line show the cut-offs for the proposed di- visions of the data set into $3,4,8$, and 6 groups (Fig. 6C). Division into six groups (the continuous red line in Fig. 6C) is consistent with previous results.

Probability plot: a probability plot, or cumulative distribution function, was calculated to make the cluster identification easier. The scatter of data was reduced and distinct straight lines were drawn to show each normal distribution, related to a uniform cluster (Fig. 6D). Six distinct straight lines were easily recognizable and the six clusters, corresponding to six appropriate hydraulic units, were in agreement the results from the histogram method.

Clustering methods (histogram, probability plot and Ward algorithm) were used to improve the classification of formation into six hydraulic units. The mean FZI values, characteristic for each $\mathrm{HU}$, were determined and used for K_core vs. $\Phi$ _core calculations (Fig. $6 \mathrm{E})$. The mean FZI values were then used to construct the porosity-permeability relationship within each $\mathrm{HU}$, using separate empirical relationships that combined $\mathrm{K} \_$core and $\Phi \_$core for each HU (Fig. 6F).

Simple statistics of permeability, porosity and $\mathrm{FZI}$ (from cores) showed that the uniform separate groups were unambiguously described by the mean value of FZI (Table 1). Finally, permeability was calculated on the basis of mean values of $\mathrm{FZI}$ for each $\mathrm{HU}$. A determination coefficient $\left(R^{2}\right)$ of 0.97 for the relationship between the calculated permeability (K_pre) and the actual permeability, measured on core plugs (K_core), indicated very good correlation (Fig. 6F).

\section{HU PREDICTION FROM CORE AND WELL LOG DATA}

Linear Multiple Regression (LMR) and ACE methods were used to predict $\mathrm{FZI}$ in the uncored parts of wells with well log data (Fig. 5). LMR was selected as an efficient statistical procedure for determining the linear relationship between a dependent variable, In(FZI_core), and independent variables, well logs or combination of well logs. Before applying the LMR methods, the ranking correlations between In(FZI_core) and individual well logs were calculated, but no simple correlations existed to predict FZI from well log data. In Table 2 the regression coefficients $(R)$ between the independent variables (logs) and the dependent variable $\ln (\mathrm{FZI})$ are presented. The results showed that the correlations were not high enough to predict In(FZI_core), on the basis of data from eight different well logs.

In the next step, to improve the correlations analysed, four groups of wells were selected, on the basis of their location in the study area (Fig. 2): G1 (Z-72, Z-74, Z-77), G2 (Z-75, Z-84), G3 (Z-76, Z-81, Z-82), and G4 (Z-78, Z-79). All of the data belong to the deltaic facies, but the sandy-shaly thinly-bedded sequence is complicated in lithology. According to results of the comprehensive interpretation of well logs it was assumed that the data in the selected clusters were more self-consistent, by comparison with the entire data set (Myśliwiec, 2006a; Matyasik et al., 2007). Calculation of the LMR prediction of In(FZI_core) in each group yielded increased correlation coefficients $(\bar{R})$, with the best result of $R=0.78$ for $\mathrm{G} 4$. To improve the multiple regression between In(FZI_core) and the well log data, min-max standardization and extra added variables (A1-A6) as combinations of well logs were 


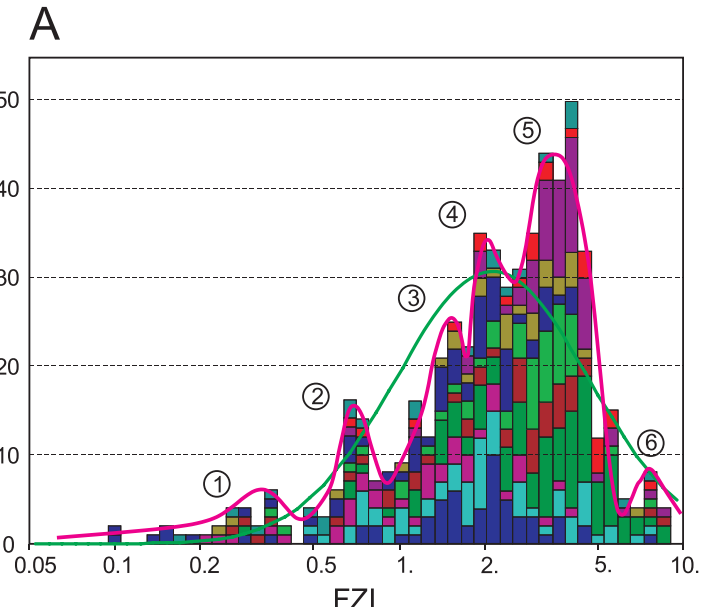

C

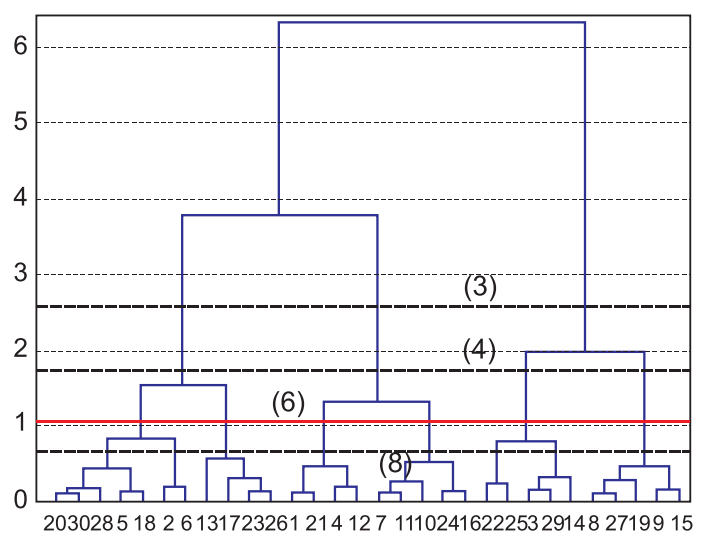

Dendrogram-clustering of the $\mathrm{FZI}$

$\mathrm{E}$

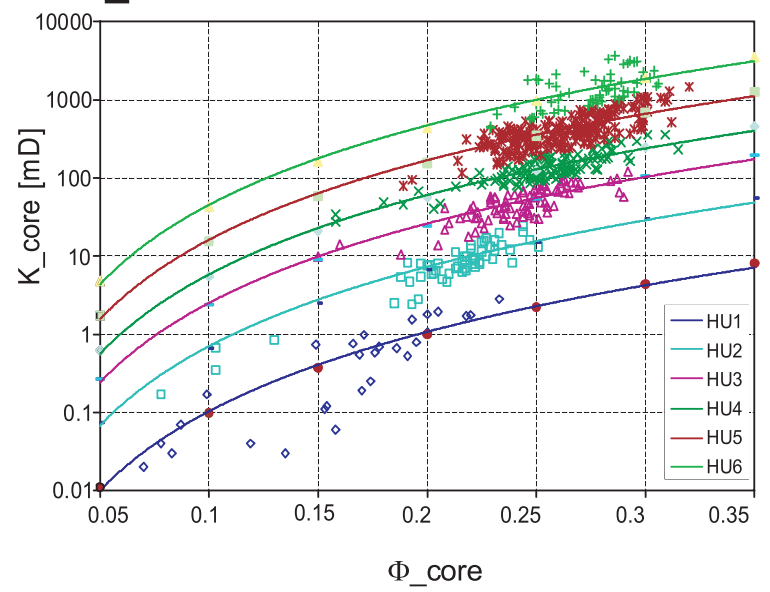

B

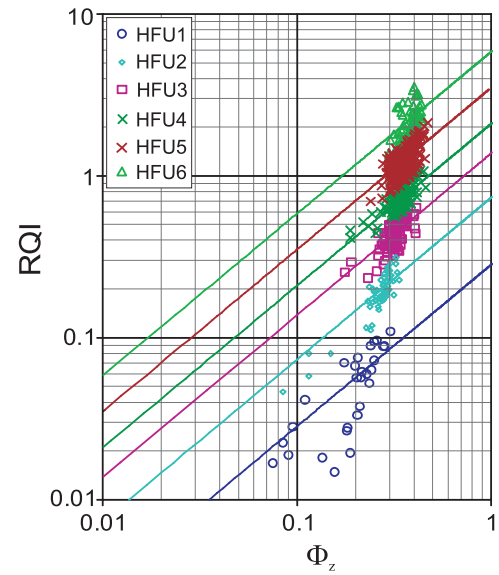

D

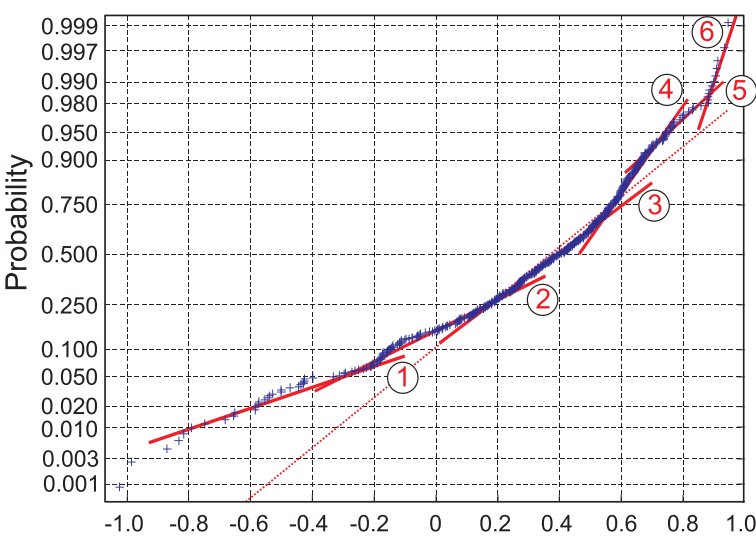

Normal probability plot of FZI

$\mathrm{F}$

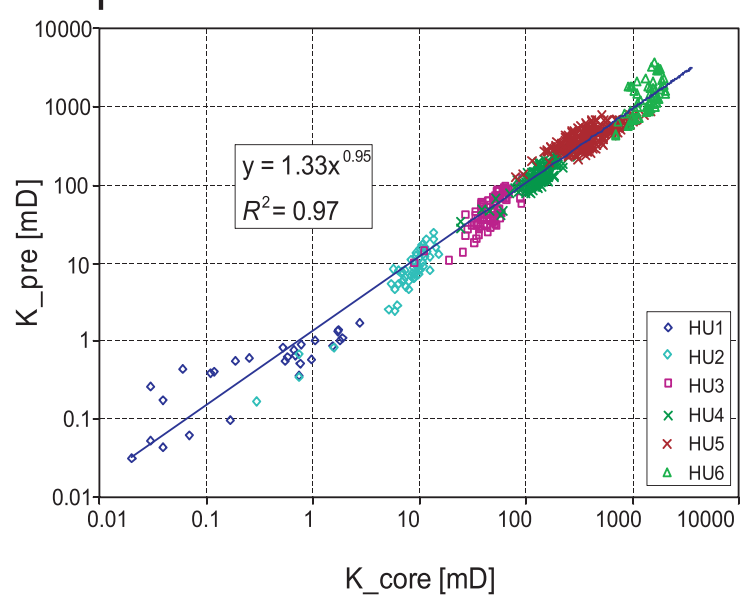

Fig. 6. Hydraulic flow unit classification on the basis of the core data
A - histogram of FZI (colours in the plot mean data from different wells); $B-\operatorname{crossplot} R Q I=\sqrt{K / \Phi_{e}}$ vs $\frac{1-\Phi_{e}}{\Phi_{e}}$;
C - dendrogram of FZI; D - probability plot of FZI; E - dispersion plot of K_core vs. $\Phi$ _core; F - K_pre vs. K_core

introduced (Ha Quang Man, 2011). The min-max standardization was done according to equation [5]:

$$
V s t=\left(V x-V_{\min }\right) /\left(V_{\max }-V_{\min }\right)
$$

where: $V x$ - current value of the variable, $V_{\min }, V_{\max }-$ minimum and maximum values of the variable, respectively, in the depth section selected for research (500-900 m).
Clustering the data, using the standardization procedure and including additional variables improved the results of the estimation of $\ln (\mathrm{FZI}$ core) on the basis of the logs (Table 3). However, the correlation coefficients remained relatively low and the ACE algorithm of Breiman and Friedman (1985) was employed to improve the estimation of In(FZI_core).

Alternating conditional expectations: the non-linear regression technique ACE was considered as an efficient variable 
Table 2

Correlation coefficients $(R)$ between $\ln (\mathrm{FZI})$ and logs

\begin{tabular}{|l|c|c|}
\hline $\begin{array}{c}\text { Number } \\
\text { of logs }\end{array}$ & Log & $R$ \\
\hline 2 & $\mathrm{E} 16 \mathrm{~N}, \mathrm{SP}$ & 0.33 \\
\hline 3 & $\mathrm{E} 16 \mathrm{~N}, \mathrm{SP}, \mathrm{DT}$ & 0.38 \\
\hline 4 & $\mathrm{E} 16 \mathrm{~N}, \mathrm{SP}, \mathrm{DT}, \mathrm{GR}$ & 0.38 \\
\hline 5 & $\mathrm{E} 16 \mathrm{~N}, \mathrm{SP}, \mathrm{DT}, \mathrm{GR}, \mathrm{NPHI}$ & 0.44 \\
\hline 6 & $\mathrm{E} 16 \mathrm{~N}, \mathrm{SP}, \mathrm{DT}, \mathrm{GR}, \mathrm{NPHI}, \mathrm{E} 64 \mathrm{~N}$ & 0.44 \\
\hline 7 & $\mathrm{E} 16 \mathrm{~N}, \mathrm{SP}, \mathrm{DT}, \mathrm{GR}, \mathrm{NPHI}, \mathrm{E} 64 \mathrm{~N}, \mathrm{EL} 14$ & 0.45 \\
\hline 8 & $\mathrm{E} 16 \mathrm{~N}, \mathrm{SP}, \mathrm{DT}, \mathrm{GR}, \mathrm{NPHI}, \mathrm{E} 64 \mathrm{~N}, \mathrm{EL} 14, \mathrm{EL} 28$ & 0.45 \\
\hline
\end{tabular}

For explanations see the text

selection method for reducing the subset of significant predictors for a considered dependent variable response (Breiman and Friedman, 1985; Xue et al., 1996; Darabos et al., 2001). The ACE algorithm estimated transformations of variables, used in a multiple regression, without any a priori assumption of a functional relationship between the dependent and independent variables. Using ACE, arbitrary measurable mean-zero transformations were defined, which yielded a maximum correlation between the primary variables and their transformations in the transformed space. Although ACE provided a fully automated approach for estimating optimal transformations, it also was decided to use heuristic reasoning in selecting logs, based on petrophysical considerations. An optimal function (f) between the transformed FZI_tr and the transformed logs using equation [6] was estimated. Finally, FZI was predicted through the reverse transformation, $\mathrm{F}-1(8)$ :

$$
\begin{gathered}
\text { FZI_tr }=f\left(\sum_{i} \log _{i} t r\right) \\
\text { FZI_tr }=F^{-1}\left[f\left(\sum_{i} \log _{i \_} t r\right)\right]
\end{gathered}
$$

where: FZI_tr was an ACE transformed FZI, and logi_tr was an ACE transformed $\log _{i}$.

On the basis of the experience of Xue et al. (1996), who performed a permeability determination from well log data, a selection was made of the best transforms of the dependent variable [In(FZI_core)] and the independent variables (well logs and combinations of well logs). The Grace program (Xue et al., 1996), based on the ACE algorithm, was used to generate an optimal correlation between a dependent variable In(FZI_tr) and multiple independent variables $\sum\left(\log _{i_{-}} t r+A_{i_{-}} t r\right)$ :

$$
\operatorname{lnFZI} \operatorname{tr}=f\left[\sum_{i}\left(\log _{i_{-}} t r+A_{i_{-}} t r\right)\right]
$$

Selected variables used in the ACE procedure are shown in Figure 7 and in Table 3. Selection was made according to the high correlation coefficient between the ACE transformed variable and the basal variable. The final correlation was determined by plotting the transformed dependent variable against the sum of the transformed independent variables. In(FZI_tr), obtained using the ACE algorithm, showed a higher correlation with In(FZI_core) than did the results from LMR (Table 3). The decision was made to use the ACE algorithm to obtain a continuous curve of the FZI_log vs. depth

The ACE procedure was applied to determine FZI, on the basis of well logs in those parts of wells where no cores were available.

\section{CLASSIFICATION OF ROCK TYPES}

Lithofacies classification involved grouping of the reservoir rocks with similar mineral composition, type and range of porosity and permeability, grain size and sorting, shaliness value and type and series of anomalies observed in the SP (spontaneous potential) log and resistivity logs. Each lithofacies corresponds to a particular depositional environment. The petrophysical grouping was based on porosity, permeability, capillary pressure and the distribution of pore-throat sizes. Both of these classifications are combined in the definition of the reservoir rock type (Varavur et al., 2005). Rushing et al. (2008) developed a classification of rock associations on the basis of the hydraulic abilities of reservoir rocks. Rock type identification was useful in well-correlation and was also important in the 3D facies modelling of the reservoir. In this study, the modelling of hydraulic units was realized using the rock type model for a better understanding of the geological basis for each hydraulic flow unit. Because of the lack of core descriptions, K-means clustering was applied for the classification of similar rock types.

\section{K-MEANS CLUSTERING FOR ROCK TYPE CLASSIFICATION}

MacQueen (1967) developed the K-means clustering algorithm, which assigned a specific number of centres $(K)$ to repre-

Correlation coefficients $(R)$ between In(FZI_core) and the results of LMR and ACE on the basis of logs and combination of logs (A1-A6)

\begin{tabular}{|l|c|c|c|c|c|}
\hline \multirow{2}{*}{ Groups } & \multirow{2}{*}{ Wells } & \multirow{2}{*}{$\begin{array}{c}\text { Number of normalized } \\
\text { samples }\end{array}$} & eight logs & $\begin{array}{c}\text { Light logs }+ \\
\text { A1 }+\ldots+\text { A6 }\end{array}$ & $\begin{array}{c}\text { eight logs }+ \\
\text { A1 + .. + A6 }\end{array}$ \\
\cline { 4 - 6 } & & & raw data & standardized data & standardized data \\
\hline G1 & Z-72, Z-74, Z-77 & 89 & 0.627 & 0.762 & 0.899 \\
\hline G2 & Z-75, Z-84 & 103 & 0.735 & 0.838 & 0.906 \\
\hline G3 & Z-76, Z-81, Z-82 & 76 & 0.627 & 0.747 & 0.889 \\
\hline G4 & Z-78, Z-79 & 45 & 0.783 & 0.884 & 0.982 \\
\hline All data (10 wells) & 313 & 0.446 & 0.507 & 0.643 \\
\hline
\end{tabular}



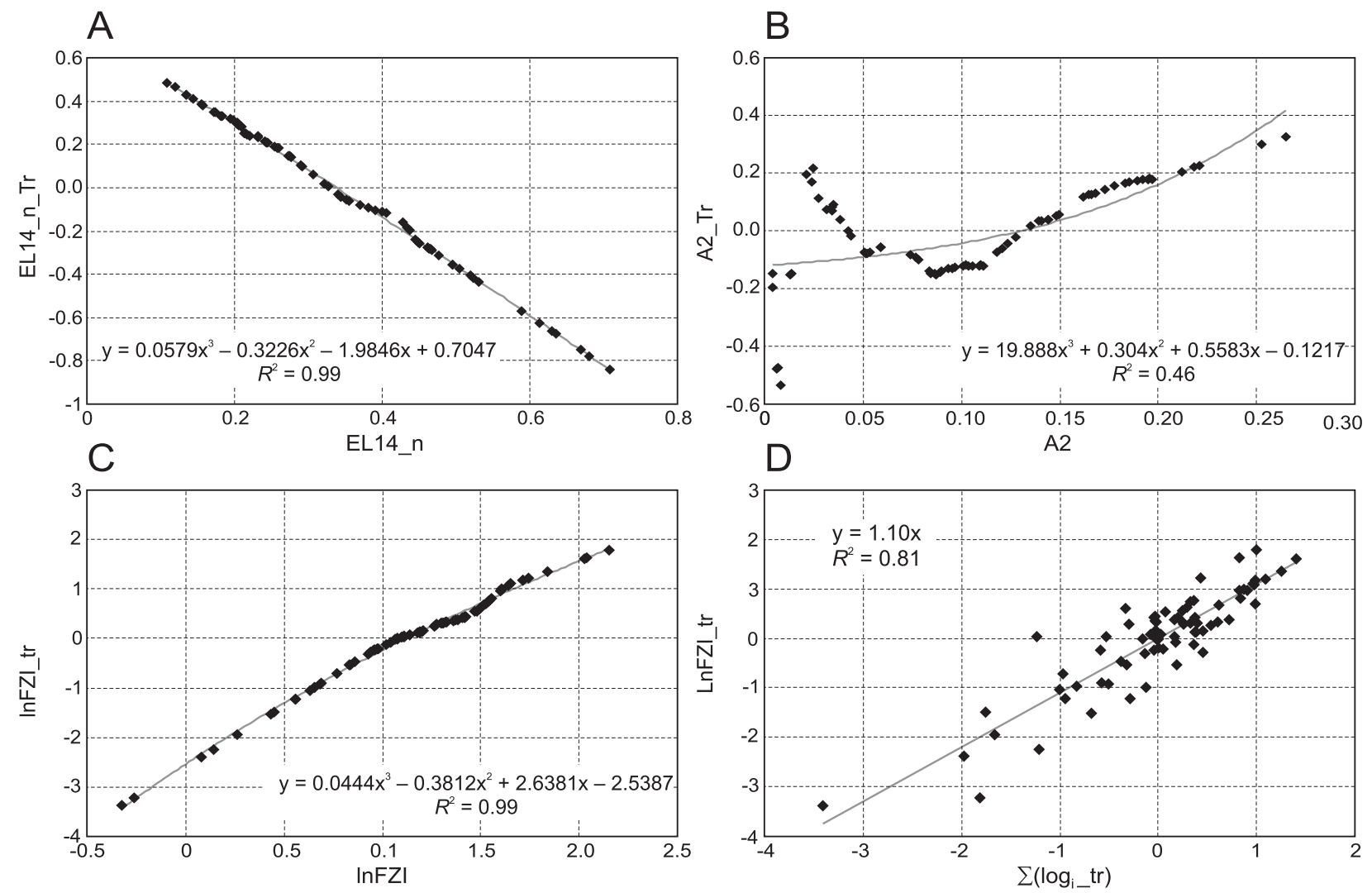

Fig. 7. Examples of ACE transformations

A - optimal transformation of EL14; B - optimal transformation of A2; C - optimal transformation of InFZI;

D - dispersion plot and correlation of In FZI_tr vs. $\sum\left(\log _{i_{-}} t r+A_{i_{-}} t r\right)$

sent the clustering of $\mathrm{N}$ points $(\mathrm{K}<\mathrm{N})$. These points were iteratively adjusted, so that each point was assigned to one cluster and the centroid of each cluster was the mean of its assigned points. In general, the $\mathrm{K}$ means technique produced exactly $\mathrm{K}$ different clusters of the greatest possible differentiation.

Logs from all wells were used for the classification of rock types in the study area. After testing, five logs were selected for the K-means clustering: GR, DT, NPHI, EN16 and EN64. The data was chosen between the top $(\mathrm{H} 1=\sim 500 \mathrm{~m})$ and base $(\mathrm{H} 2$ $=\sim 900 \mathrm{~m}$ ) of the reservoir selected for testing.

Two stages were applied for K-means clustering (Michael, 1999). Firstly, the data were divided into fourteen clusters to cover all the different data ranges visible in the well logs (Fig. 8A). Finally, six clusters, corresponding to six rock types (RT), were selected. The crossplot of GR and EN64 clearly showed six rock types in the reservoir (Fig. 8B).

Six clusters, related to six rock types, were obtained as combinations of the primary division into fourteen groups. The rock types, shown in colours (Fig. 8B), were correlated with the GR curves and the hydraulic units (Fig. 9). An increase in the deflection for the GR curve means an increase in shaliness and a corresponding decrease in the potential for fluid flow. A good visual relationship was observed between the GR deflections, rock types and hydraulic units (Fig. 9). The best hydraulic properties were related to the facies in light blue; the rock type in light blue corresponds to the lowest intensity of natural radioactivity (Fig. 8B).

\section{RELATIONSHIP BETWEEN HYDRAULIC FLOW UNITS AND ROCK TYPES}

To understand the geological and petrophysical control for rock types, Svirsky et al. (2004) investigated available results of sieve analysis, thin sections and other special core analyses, giving information about grain size, sorting, pore geometry and mineral composition. This geological and petrophysical background demonstrated vital links between micro-characteristics of pores and the commonly available well log data used for $\mathrm{HU}$ prediction in uncored wells. Rock types were used to link depositional facies and wireline log responses. They were also used (Mikes et al., 2006) to connect the static models (geological models or reservoir models) and dynamic models (flow unit models).

The transformation of facies into hydraulic units, that is, the geological model into a reservoir model, was not a simple task. The value of this approach was that the reservoir model preserves the spatial distribution of facies which controls flow on a regional scale. This made the method an efficient tool for the rapid modelling of fluid flow through a reservoir, permitting also sensitivity analysis (Mikes et al., 2006). Hydraulic units were related to lithological facies (rock types), but their boundaries did not necessarily coincide with facies boundaries (Abbaszadeh et al., 1995). The results of rock type classification and hydraulic unit determination for the data of well group G3 are shown in Figure 9. Anomalies observed in Figure 9 lead to the following conclusions:

- rock type (facies) distribution could serve as a basis for reservoir models; 

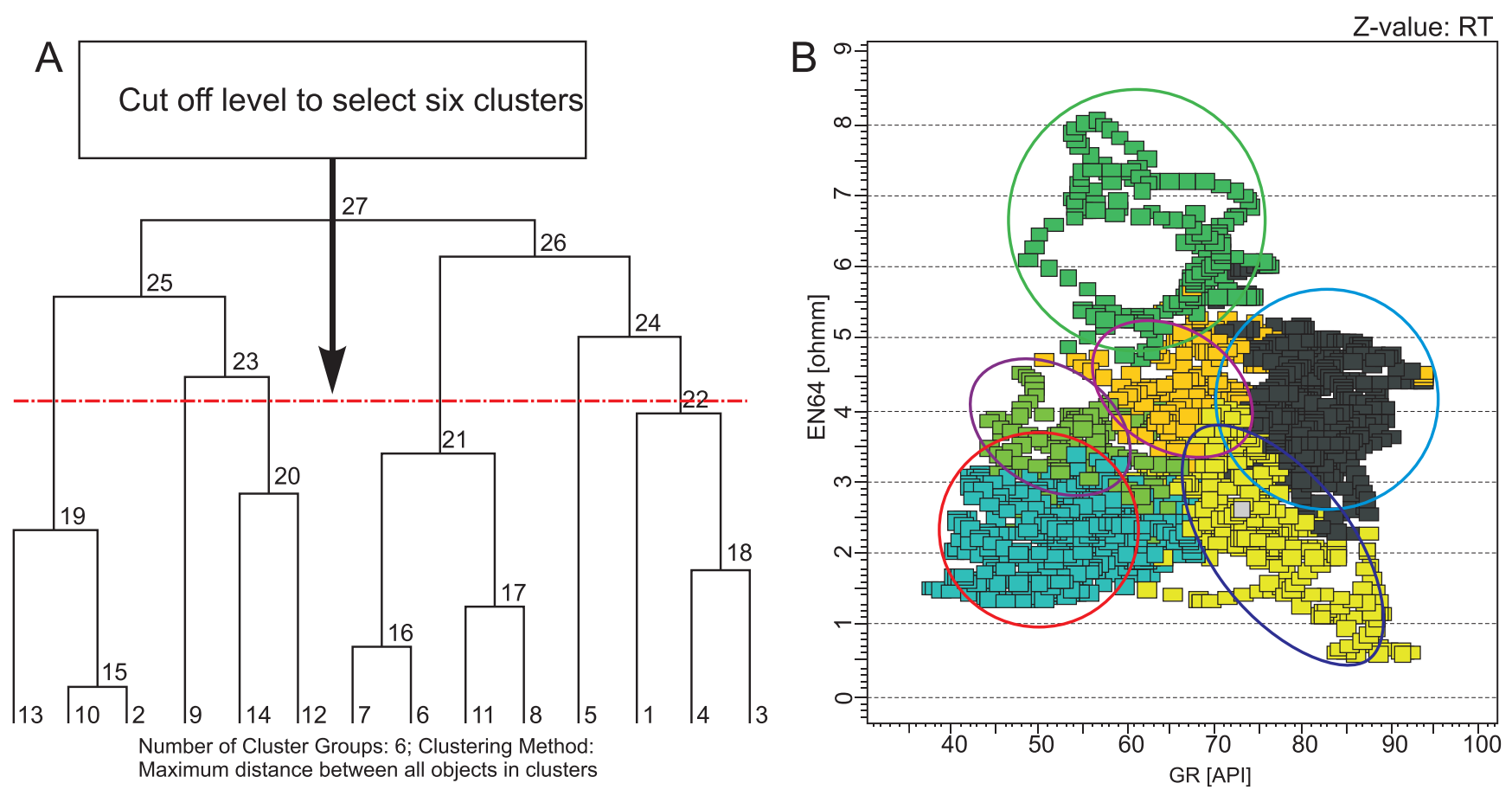

Fig. 8. Results of K-means clustering for the well group G3

A - six clusters shown on the dendrogram; B - crossplot of GR vs. EN64 responding to six rock types (RT)

- hydraulic flow units and facies were key elements of the reservoir model and geological model, respectively;

- reservoir models could be based on a small number of units, with reference to all levels of lithologic heterogeneity, the spatial distribution of facies/flow units and their hydraulic flow properties.

\section{GEOSTATISTICAL MODELLING}

Geostatistical modelling is an essential part of the main modelling workflows (Figs. 1 and 5). To create the fluid flow simulation, the hydraulic flow units were modelled with reference to the rock type model. In the next step, the porosity model and permeability model were formulated within the limits imposed by the $\mathrm{HU}$ model.

Structural modelling: the mis-tie correction was applied for 2D seismic. Four horizons: $\mathrm{H} 1, \mathrm{H} 2, \mathrm{H} 3$ and $\mathrm{H} 4$ - were mapped at depths from 544-938 m, constituting the reservoir base volume (RBV; Fig. 10) corresponding to the identified tops of the four horizons: Top_7, Top_12, Top_15 and Top_17 (Fig. 10A). The depths of the tops (Table ${ }_{4}$ ) were taken from the PGNiG Warszawa, Branch in Sanok, Jasło Office according to the velocity model adopted in the interpretation (Bosak, 2007). Four surfaces, corresponding to the tops of the four horizons, were mapped (Fig. 10B). In the next step, 3D grid blocks within the reservoir base volume (RBV), and four surfaces were created (Fig. 11A) dividing RBV into 3 zones: Zone 1, Zone 2 and Zone 3.

Initially, in order to capture all the reservoir properties in detail, a model was created based on a horizontal grid having $50 \mathrm{~m}$ cell size. In the vertical direction ( $\mathrm{Z}$ ), a grid size of about 1 metre was used as the layer scale. The RBV was divided in this way into 189 layers. This led to a grid that was $170 \times 168 \times$
198 units in size and contained 8,934,354 grid cells in total. Since it was assumed that there were no faults in the reservoir, the gridding process was simplified and faults were not taken into account.

Converting 2D seismics to pseudo-3D seismics: in the study area, the 2D seismic survey comprises 25 lines (Fig. 4). As a first step, the 2D seismic results were converted to a pseudo3D seismic cube, using the SGS method. The main steps for converting the $2 \mathrm{D}$ seismic survey to a pseudo-3D seismic cube are shown in the workflow (Fig. 5, left column). The volume of the pseudo-3D seismic cube was limited to the RBV - study interval, between the top of horizon $\mathrm{H} 1$ and the bottom of horizon $\mathrm{H} 4$ (Fig. 10A). The SGS technique was applied to interpolate seismic amplitudes and times in three directions. The result outcome is termed the "3D seismic" cube and the amplitude model is shown in Figure 11A.

The seismic amplitudes in both models, the pseudo-3D seismic cube and the 2D seismic lines, were compared for the purpose of validation (Fig. 11B). The comparison of amplitude for points, common to both models (wells), indicated clearly that the pseudo-3D seismic data was well matched to the $2 \mathrm{D}$ seismic data. The next step involved using the pseudo-3D seismics for seismic facies classification.

\section{SEISMIC FACIES CLASSIFICATION}

Seismic signatures of geological facies are related to the lithology, fluid content, porosity and geometry of the geological body. Depositional processes and environments of deposition are also considered (Roksandić, 2006). In the study presented, seismic facies classification was carried out on the basis of correlations between the seismic attributes and well log records. 

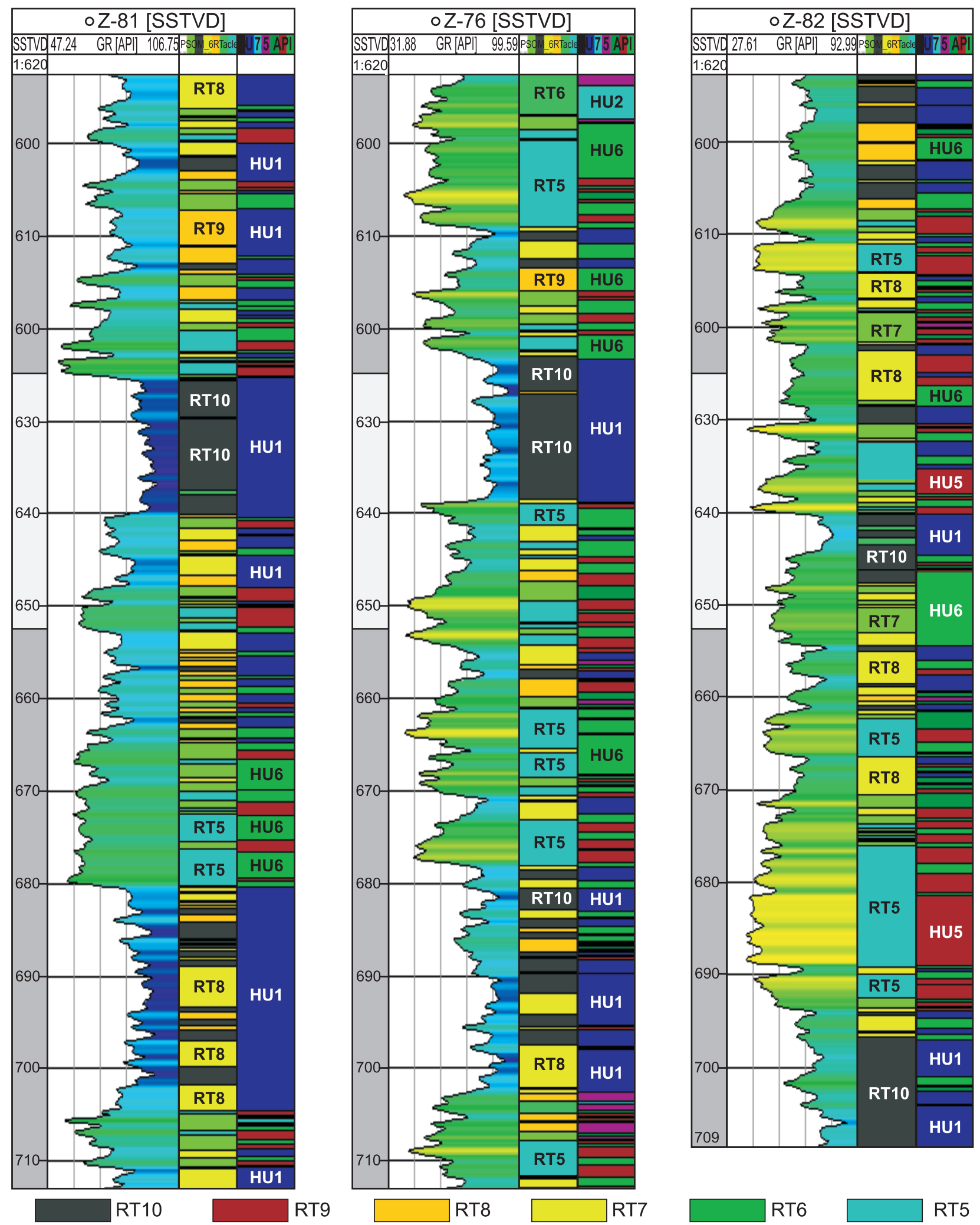

Fig. 9. Comparison between six rock types and six hydraulic flow units, HU in wells of group G3: Z-81, Z-76, Z-82; the first, left track present true vertical depth (595-714 m, vertical scale 1:620 and 595-709 m, vertical scale 1:595); the second track present GR (colours in GR area are illustration of changes in shaliness; an increase in the deflection for the GR curve means an increase in shaliness and a corresponding decrease in the potential for fluid flow; a good visual relationship was observed between the GR deflections, rock types and hydraulic units); the third track illustrate rock types (RT5-RT10, colour scale is below the plots); the fourth tracks illustrate Hydraulic Units (HU1-HU6, in the same colours as in Figure 6) 
A
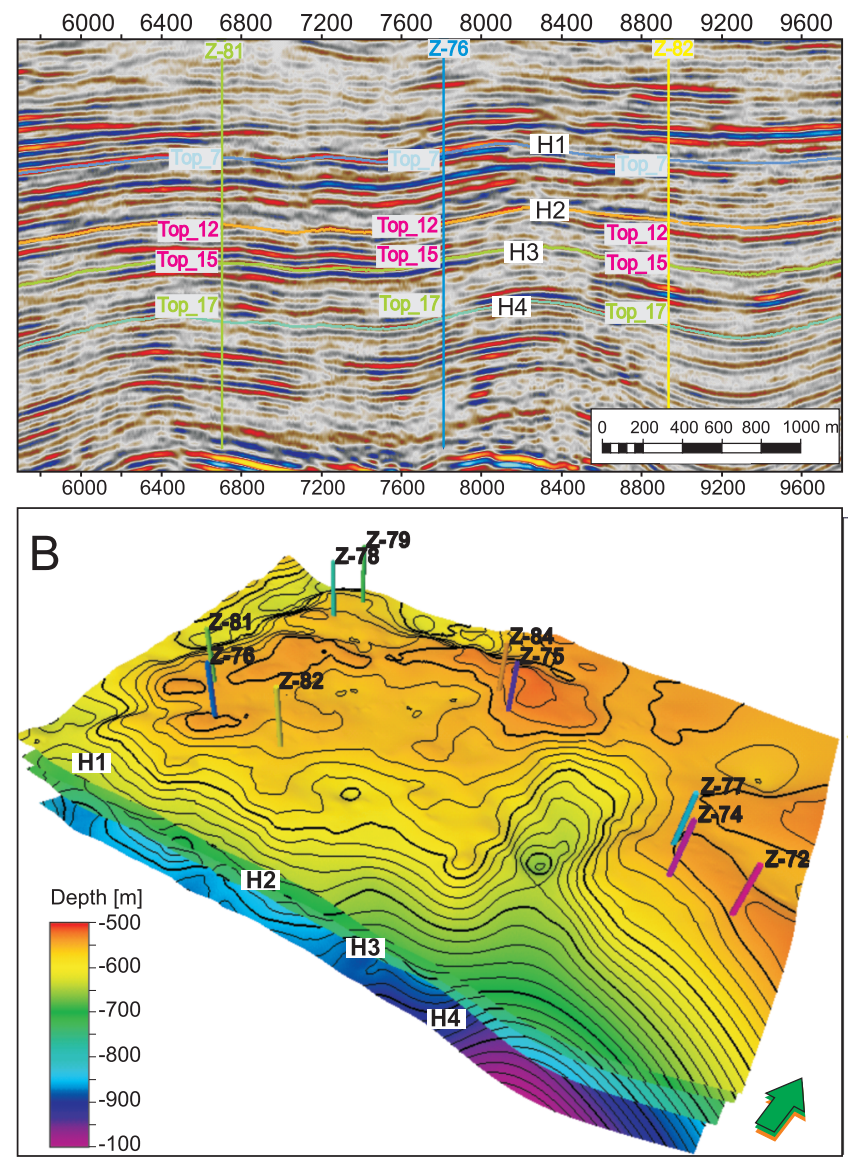

Fig. 10. Results of structural interpretation

A - part of seismic section along line 24-5-02k, four horizons presented on the basis of interpreted well-tops: Top_7 - H1, Top_12 H2, Top_15- H3 and Top_17- H4; B - depth of 3D structure model in the study area; four surfaces were created for the four horizons $\mathrm{H} 1-\mathrm{H} 4$ (according to Bosak, 2007)

Because of the small number of wells in the study area and their irregular distribution, the UNN method was applied to improve the results for seismic facies distribution in the reservoir body volume. The seismic attributes selected, i.e. relative acoustic impedance and sweetness and envelope (Chopra and Marfurt, 2005), and amplitude (measured data) were input for UNN processing and the output resulted in seismic facies classes. The relative acoustic impedance as a simplified inversion result was used for lithology discrimination and as a thickness variation indicator (Suarez and Marfurt, 2008). Sweetness was useful for channel detection in deep-water clastic settings (Hart, 2008).

The main issue in choosing the number of facies classes was to find the balance between the statistical outcomes and real geological units. The assumption was made that different facies have distinctive petrophysical properties and spatial features that could provide a basis for modelling (Deutsch, 2002). Initially, ten facies were used in the UNN processing, in order to distinguish all possible facies in the data. The number of facies and the percentage of data for each facies were considered in the process of the facies selection. Ultimately, six facies corresponding to six rock types from the well log data and six HUs from the laboratory data, were selected. The difference between ten and six seismic facies is shown in Figure 12. In the upper panel (Fig. 12A), a great diversity of facies was difficult to explain in terms of geology and petrophysics. The result giving
Table 4

Depths of the tops of the horizons defined in the $Z$ Gas Field (according to Bosak, 2007)

\begin{tabular}{|c|c|c|c|c|}
\hline Well & $\begin{array}{c}\text { Top_7 (H1) } \\
{[\mathrm{m}]}\end{array}$ & $\begin{array}{c}\text { Top_12 (H2) } \\
{[\mathrm{m}]}\end{array}$ & $\begin{array}{c}\text { Top_15 (H3) } \\
{[\mathrm{m}]}\end{array}$ & $\begin{array}{c}\text { Top_17 (H4) } \\
{[\mathrm{m}]}\end{array}$ \\
\hline Z-72 & 547 & 764 & 882 & 938 \\
\hline Z-74 & 548 & 762 & 879 & 933 \\
\hline Z-75 & 540 & 656 & 698 & 777 \\
\hline Z-76 & 550 & 657 & 701 & 773 \\
\hline Z-77 & 550 & 767 & 884 & 936 \\
\hline Z-78 & 566 & 682 & 727 & 805 \\
\hline Z-79 & 576 & 698 & 740 & 823 \\
\hline Z-81 & 552 & 657 & 701 & 776 \\
\hline Z-82 & 567 & 670 & 717 & 794 \\
\hline Z-84 & 544 & 663 & 701 & 783 \\
\hline
\end{tabular}

six facies revealed a more consistent facies image, in terms of the corresponding seismic reflections (Fig. 12B).

The six seismic facies F5-F10 (Fig. 12B) were marked with the same colours as the six rock types (Fig. 8B). The light blue signified the parts with the best reservoir properties. The black colour was used to specify facies with low potential for fluid flow. The original seismic display is shown in Figure 10A.

The pseudo-3D seismic cube permitted the interactive blending of multiple seismic volumes representing various attributes to isolate areas of interest and conceptualize them as 3D objects (geobodies). In the next step, 3D objects were assigned to geological structures and provided with geological interpretations. The geobodies were included directly in the $3 \mathrm{D}$ geological model, bridging the gap between geophysics and geology.

The envelope attribute was applied to extract the probable geobodies for the deltaic sedimentary environment in the study area (Fig. 13). The main trend of the channel system in this interval from south to east and the delta lobe were clearly defined in the eastern part. The G3 group of wells (Z-76, Z-81, Z-82) and the G4 group of wells (Z-78, Z-79) were drilled in the western part of the study area, where a complex distribution of facies was observed (Fig. 13).

Wells of the G2 group (Z-75, Z-84) were drilled in the channel system (middle part) and wells of the G1 group (Z-72, Z-74, Z-77) were drilled in the eastern part of study area, where the delta lobe facies was recognized. Because of the low $(10 \mathrm{~m})$, vertical resolution of the pseudo-3D seismics the outcomes gave only a generalized picture of facies distribution (geobodies) in the study area. The six facies, marked by colours, corresponding to the core data and well log records (six hydraulic units), were not clearly visible. In the next step, rock types were incorporated in the classification of seismic facies to improve facies modelling.

\section{ROCK TYPE MODELLING}

Lithology within the reservoir could be interpreted from raw seismic data (amplitudes) due to the relationship between the seismic wavelength and geometrical size of sandy-shaly layers. Similarly, geological features could be directly derived from the seismic attributes. The UNN result for six facies (Fig. 14A) showed the distribution of facies on the surfaces (recurrent on horizons $\mathrm{H} 1-\mathrm{H} 4$ ), which could be explained on the basis of geological knowledge, well log data and seismic data. The lateral facies distribution obtained was accepted on the basis of the similarity between facies distribution and the occurrence of various seismic attributes. The vertical facies distributions from the 

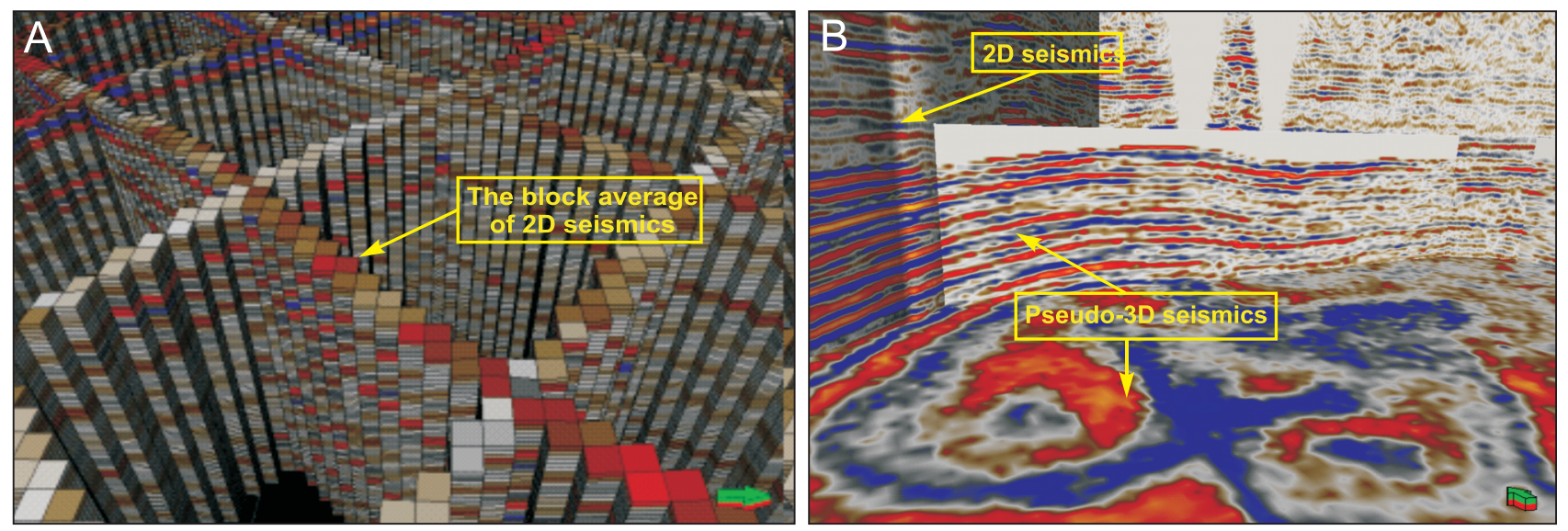

Fig. 11. Pseudo-3D seismic cube

A - block average data of $2 \mathrm{D}$ seismics after upscaling into $3 \mathrm{D}$ grid;

B - comparison between 2D seismic profiles and pseudo-3D seismic cube

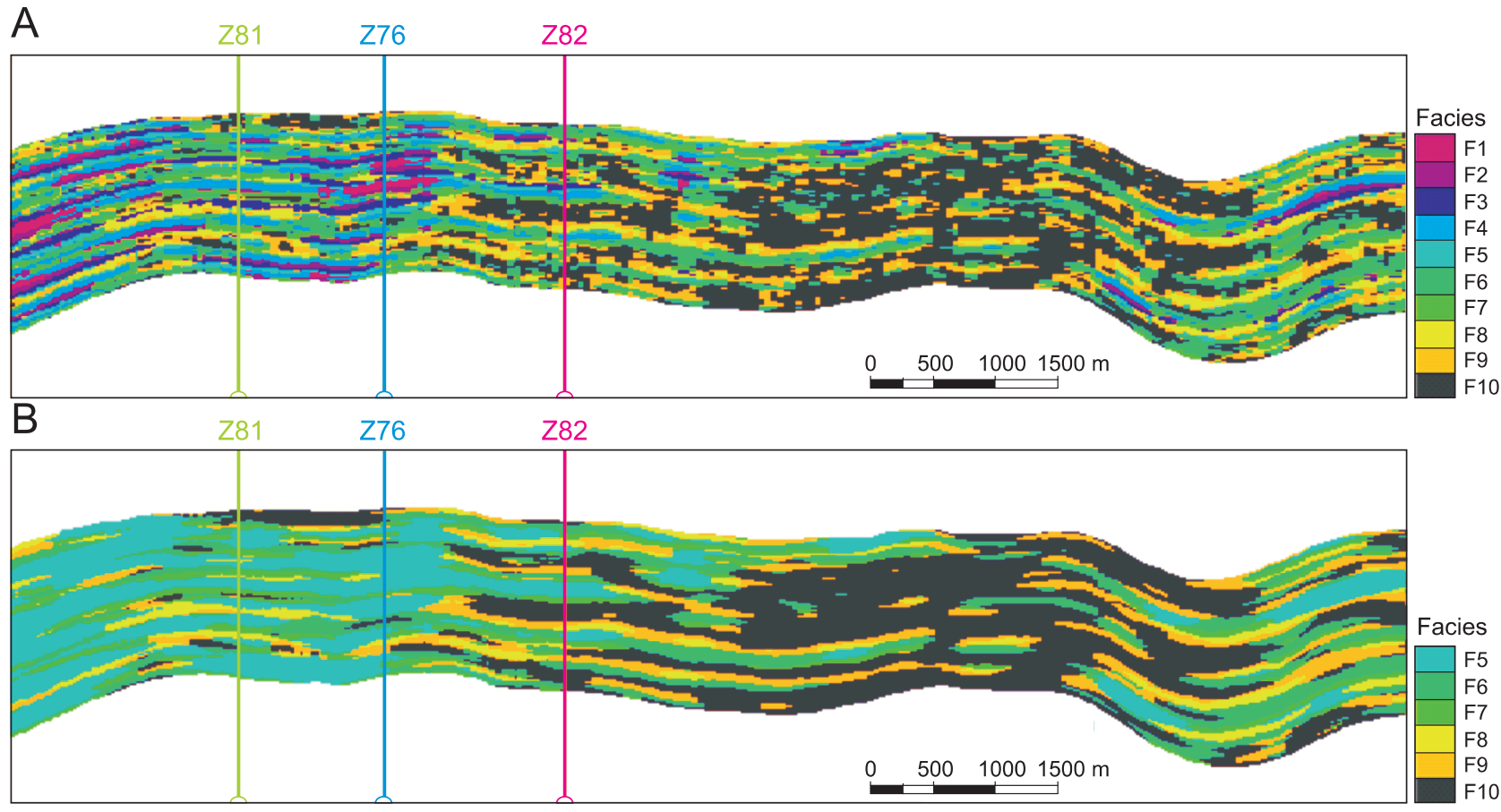

Fig. 12. Cross-section of seismic facies classification results (H1-H4 section) from the UNN method

$$
\text { A - } 10 \text { facies; } \mathbf{B}-6 \text { facies }
$$

boreholes were not entirely confirmed by the lithological types distinguished on the basis of well logging, because of the poor vertical resolution of the seismic data for the thin-bedded, sandy-shaly strata (Fig. 14B).

The thickness of the facies was small (tens of centimetres), relative to the seismic vertical resolution $(10 \mathrm{~m})$ and so the facies distribution could not have been obtained using seismic data only. In Figure 14B the result of the 6RT_log (result of the division of the formation into six rock types on the basis of logs) was included in wells Z-81, Z-76 and Z-82. Colours related to facies were not in agreement. In the next step, the 6RT_log results and the 6Facies_UNN results were combined (Fig. 14C, D). Stochastic classification, using SIS, was applied to obtain results in agreement with the well data at each well location, and improved the horizontal resolution, related to the uneven, spatial distribution of the wells. The resulting model of facies distribution 6RT_SIS in the reservoir body volume is shown in Figure 14C. The seismic facies section in Figure 14D shows a good match between the 6RT_SIS model and the 6RT_log model in wells Z-81, Z-76 and Z-82.

HYDRAULIC FLOW UNITS AND RESERVOIR PROPERTIES

The six hydraulic flow units $(6 \mathrm{HU})$ defined were entered into the 3D grid (referring to workflow shown in Fig. 5). In order to control the distribution of HU, the 6RT_UNN_SIS (resulting division 


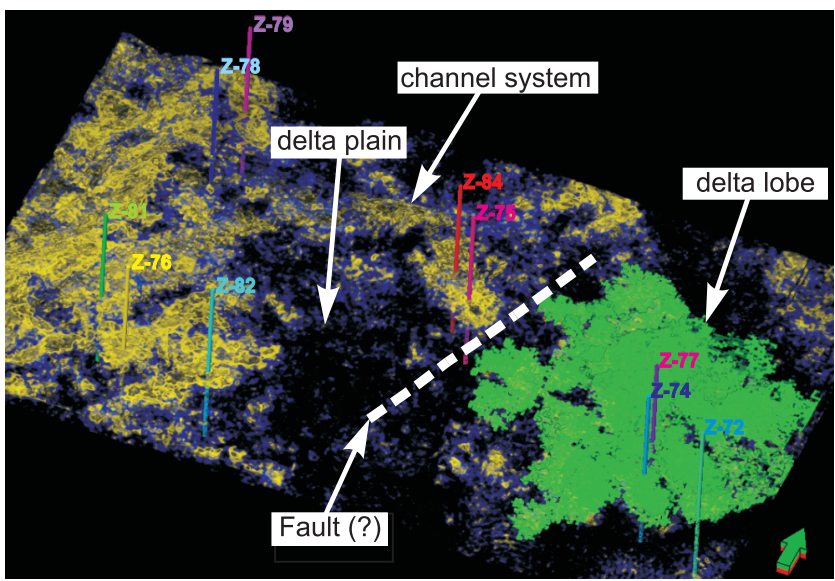

Fig. 13. Channel system and delta lobe facies from pseudo-3D seismic extraction in the study area

of formation, by the statistical method SIS, into seismic facies by using the Unsupervised Neural Network controlled by results of well logging) was used. The resulting model 3D 6HU_SIS (final $3 \mathrm{D}$ division of the formation into hydraulic units) is shown in Figure 15A. To make a comparison to the seismic facies distribu- tion, the 3D 6Facies UNN SIS distribution (six seismic facies distribution resulting from the Unsupervised Neural Netwok improved by rock types from well logging) was included.

The final step of the static modelling was properties modelling. Owing to the complex variation in permeability within the reservoir model, the porosity from the well logging interpretation $(\mathrm{PHI})$ was first established and then the permeability was calculated. Generally, permeability modelling was done using SGS and co-kriging with a porosity model. Permeability was calculated from the porosity model using the Kozeny-Carman equation [1].

The SGS method was applied to interpolate porosity into the $3 \mathrm{D}$ grid, corresponding to the six facies model (6Facies UNN SIS) and six hydraulic flow units model, 6HU SIS (Fig. 15B). High porosity values correlated with HU6s, HU5s and HU4s and low porosities with HU1s, HU2s and HU3s.

In the final stage, the permeability modelling was carried out (Fig. 5). Equation [4] was applied to calculate the 3D permeability model (K_HU), on the basis of 3D 6HU_SIS and 3D PHI_HU and FZI_mean (Fig. 15C).

The distribution of HUs from static modelling (Fig. 15A) was in agreement with the distribution of seismic facies (Fig. 14C; 3D 6RT UNN SIS). Seismic facies colored in black correspond to hydraulic unit one, HU1, in dark blue. Hydraulic unit HU1 has the lowest potential for fluid flow (Table 1 and Fig. 9). The facies in light blue corresponded to the rock type in light blue (Fig. 14). The facies in black were related to rock types rep-
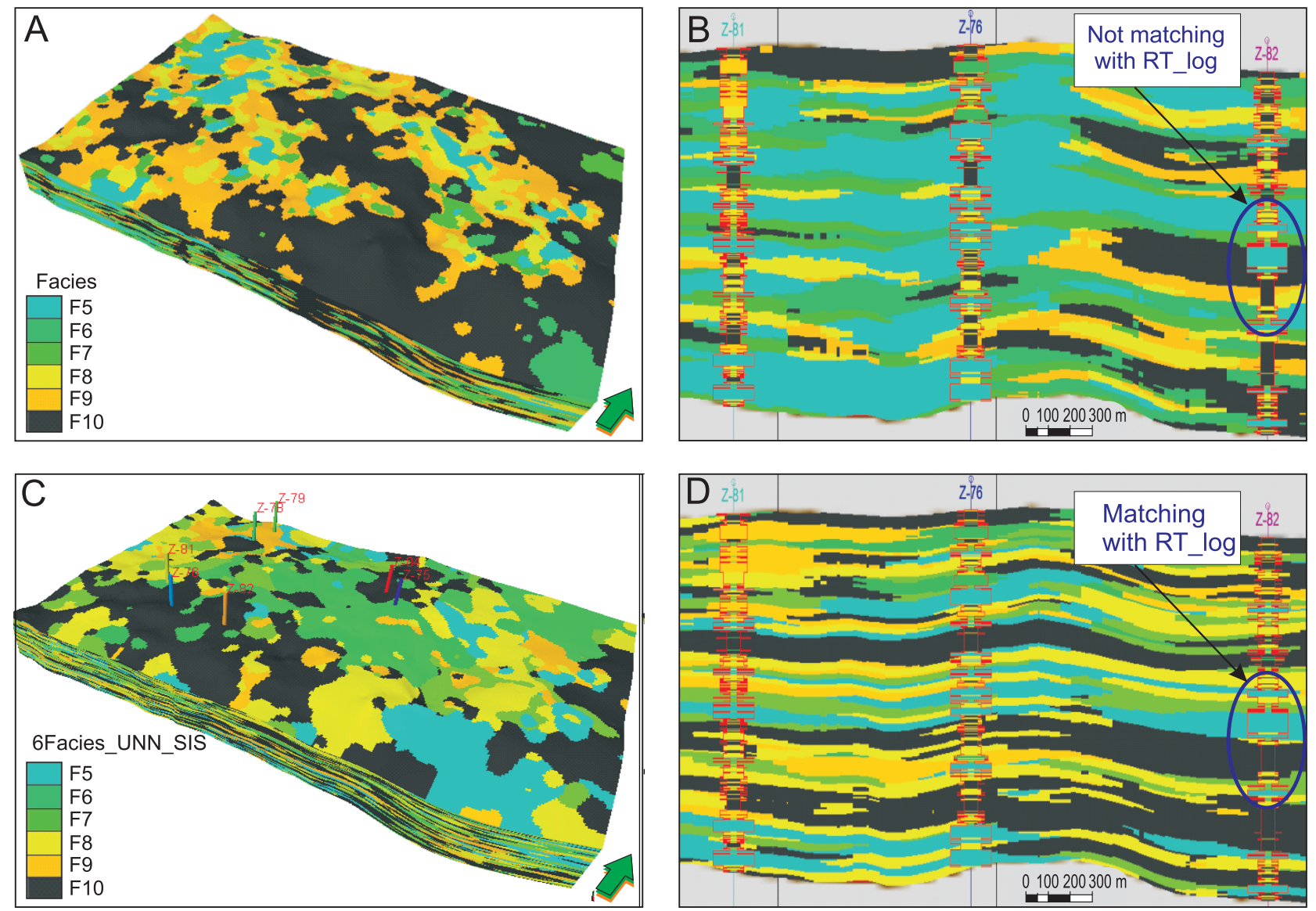

Fig. 14. Facies distribution in the reservoir body volume

A - deterministic results - 3D 6Facies_UNN model; B - 6Facies_UNN seismic section with included 6RT_logs in wells Z-81, Z-76, Z-82; C - stochastic result - 3D 6RT UNN SIS model; D - stochastic result - 3D 6RT UNN SIS model with included 6RT logs in wells Z-81, Z-76, Z-82 

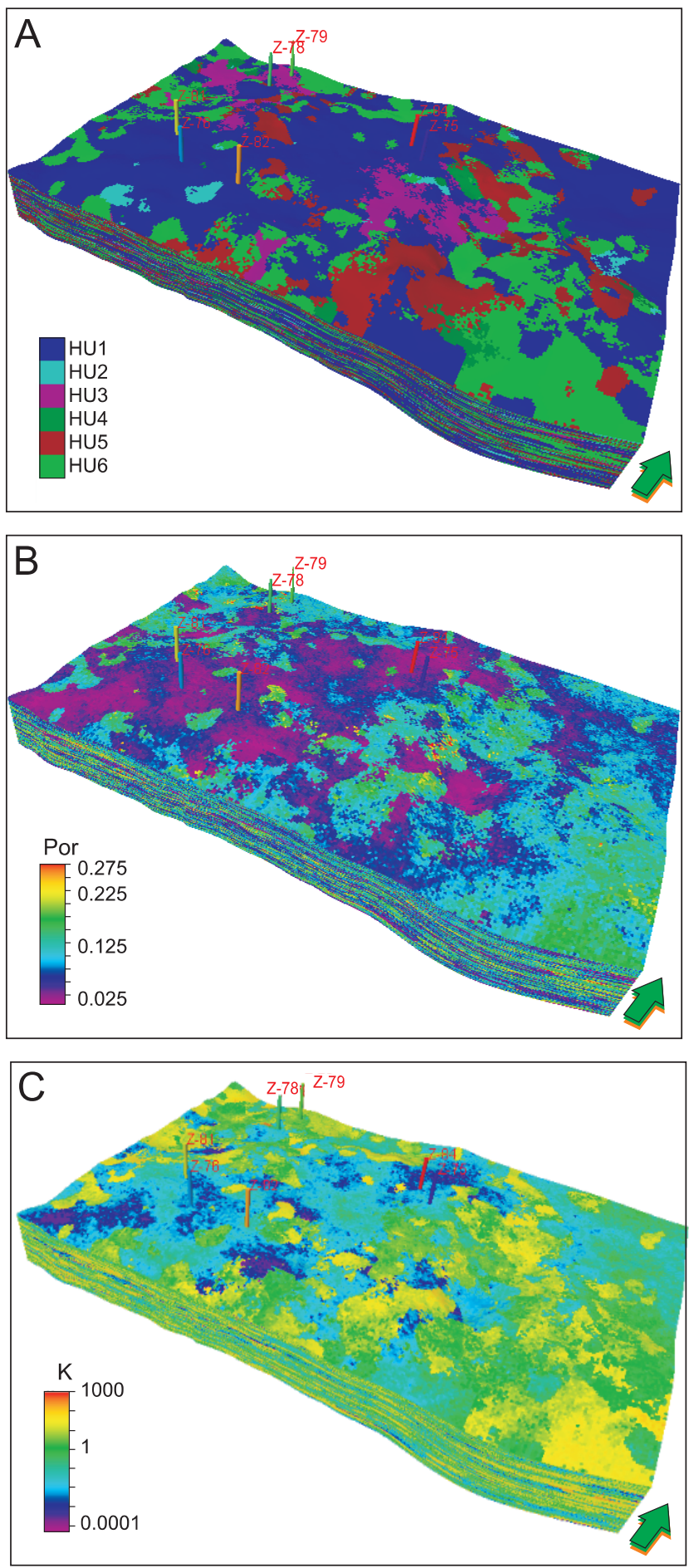

Fig. 15. Results of static modeling

A - distribution of 3D $6 \mathrm{HU}$ SIS obtained on the basis of 6Facies_UNN_SIS; B - results of static modelling; distribution of 3D PHI_HU obtained on the basis of $6 \mathrm{HU}$ SIS; C - results of static modelling; distribution of 3D K HU obtained on the basis of PHI HU

resented in black (Fig. 8). The cross-plot of 3D K_HU vs. 3D $\mathrm{PHI}$ HU shows a clear relationship between $\mathrm{K}$ and $\mathrm{PHI}$ in each $\mathrm{HU}$ (Fig. 16A). A correlation was noted between the permeability from logs (K_log) and the permeability, calculated for the 3-D model (Fig. 16B). The permeability, calculated for the first hydraulic unit, HU1, was slightly smaller than the $\mathrm{K} \_l$ log value, but in other hydraulic units the correlation is good.

\section{CONCLUSIONS}

A case study was performed in the $Z$ gas accumulation referable to a group of Miocene gas reservoirs in part of the Carpathian Foredeep of Poland. In the section of the Z Gas Field examined, the depositional environment of the reservoir strata is deltaic. The reservoir rocks were a sandy-shaly, thinbedded succession, which varied not only in thickness, but also in lateral extent. Despite the challenges presented by the complicated lithology and their petrophysical properties, a range of geophysical, geological, and geostatistical modelling techniques were used to reach the following conclusions:

- The hydraulic flow unit technique, developed by oil-industry researchers and routinely applied to problems of identifying reservoir characteristics in a wide range of deposits, proved to be effective in the gas field studied. In this study, the data from 570 core plugs (PHI_core and K_core) from ten wells were classified into six hydraulic flow units $(6 \mathrm{HUs})$ by applying conventional cluster analysis techniques.

- Statistical methods proved to be useful, flexible and effective. LMR and ACE were tested and yielded acceptable results. Both methods were used to integrate core and log data in calculations of the $\mathrm{FZI}$ and to divide the reservoir, penetrated by each well, into hydraulic flow units $(\mathrm{HU})$. In the study, the optimal ACE transformations of dependent (FZI) and independent (logs) values were derived to improve the correlation of the FZI from core and well log data.

- In the absence of core descriptions, the six rock types were classified by the $\mathrm{K}$ mean clustering method, applied to well log data. The resulting classification was used as a reference framework in the determination of the distribution of hydraulic units.

- A pseudo-3D seismic cube was created from a high-density grid of $252 \mathrm{D}$ seismic profiles, using the Sequential Gaussian Simulation technique. This facilitated the process of mapping the deltaic facies and revealed a channel system.

- A UNN was used to classify the pseudo-3D seismic attributes, amplitude (raw data) and relative acoustic impedance and envelope and sweetness, into six seismic facies (6Facies_UNN). Rock type modelling, using the Sequential Indicator Simulation technique, helped to overcome the limitation of the seismic scale by combining well log (RT) and seismic facies (6Facies_UNN).

- Six hydraulic flow units were modelled, using the Sequential Indicator Simulation technique, and were controlled by the six rock types model. Since the method incorporated the facies distribution, extracted from the pseudo-3D cube, the resulting 3D HU model was not only dependent on petrophysical properties $(\mathrm{K}, \mathrm{PHI})$, but also was controlled by stratigraphy.

- To reduce uncertainty in the applied geostatistical methods and to maximize the advantages of applying the hydraulic flow unit technique, the 3D permeability model was calculated directly from the 3D porosity model, constrained by the $\mathrm{HU}$ model (using the Kozeny-Carman equation). The results showed a good correlation between the permeability, determined from well log data, and the calculated 3D permeability.

- Static models of seismic facies, rock type, hydraulic flow units and reservoir properties, i.e. porosity and permeability, were the basis for fluid flow modelling. The methodology can be applied to other reservoirs in the Miocene succession of the Polish part of the Carpathian Foredeep and at other locations where a dense network of 2D seismic data is available. 

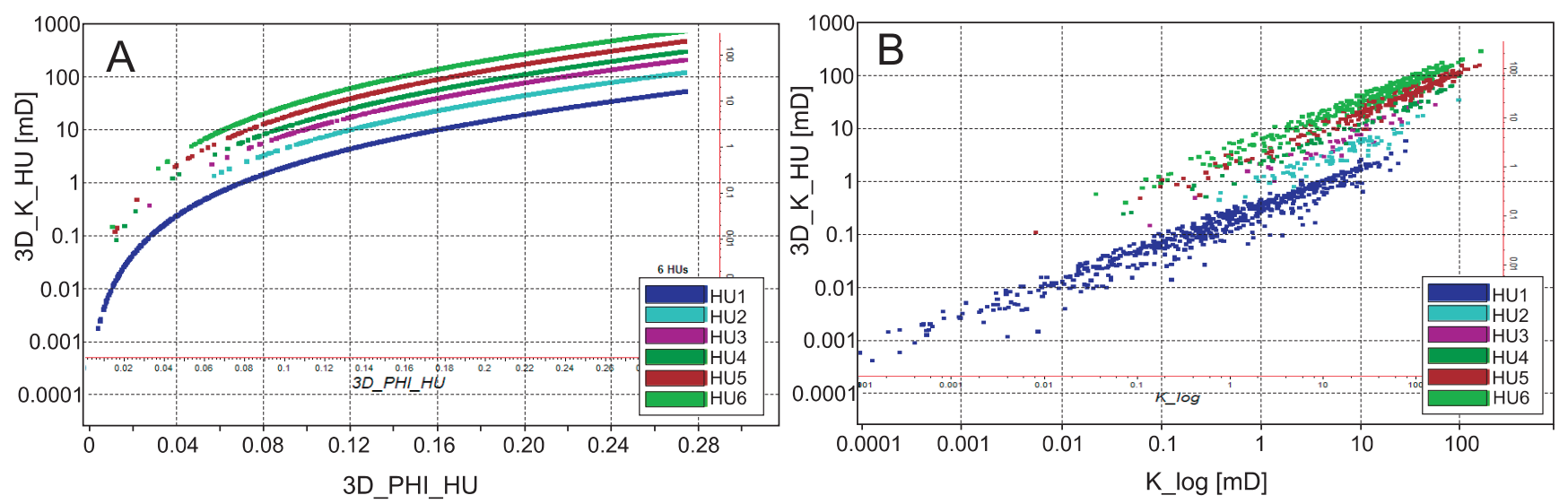

Fig. 16. Cross plot of permeability

\begin{abstract}
A - corresponding to each $\mathrm{HU}(3 \mathrm{D}$ K_HU) vs. porosity from modelling (3D PHI_HU);
B - permeability from logs ( $K \_$log) vs. permeability from 3D modelling (3D K_HU)
\end{abstract}

Acknowledgements. These investigations were supported financially via a Ph.D. project of the Ministry of Science and Higher Education in Poland No N N525 3953739, 2010-2011, and by a fund from the Department of Geophysics, Faculty of Geology, Geophysics and Environment Protection, AGH University of Science and Technology, Kraków, Poland, 2007-2010. The results presented are part of the Ph.D. thesis by $\mathrm{Ha}$ Quang Man, "Integrated reservoir characterization for fluid flow modelling of the $Z$ gas deposit at the Carpathian Foredeep", prepared at the AGH University of Science and
Technology, Kraków, Poland, Faculty of Geology Geophysics and Environmental Protection. The static modelling was done using Petrel@software, thanks to a University grant to AGH UST, Kraków, Poland from the Schlumberger Company. The authors thank PGNiG S.A. Warszawa, Poland, for making data available for this research. The authors are grateful to the reviewers for their suggested amendments, which has made the paper clearer for readers.

\title{
REFERENCES
}

Abbaszadeh M., Fujii H., Fujimoto F. (1995) Permeability prediction by hydraulic flow units - theory and applications. Paper SPE 30158 presented at the 1995 SPE PetroVietnam Conference, Ho Chi Minh, Vietnam, 1-3 March.

Amaefule J.O., Altunbay M., Tiab D., Kersey D.G., Keelan D.K. (1993) Enhanced reservoir description: using core and log data to identify hydraulic (flow) units and predict permeability in uncored intervals/wells. Paper SPE, 26436: 205-220.

Bała M. (2011) Evaluation of electric parameters of anisotropic sandy-shaly Miocene formations on the basis of resistivity logs. Acta Geophysica, 59: 954-966.

Bohling G. (2005) Stochastic simulation and reservoir modeling workflow: C\&PE 940, http://people.ku.edu/ gbohling/cpe940/Simulation.pdf

Bosak B. (2007) Dokumentacja geologiczna złoża gazu ziemnego Z-L. Dodatek 5, Jasło 2007, D/G.239, PGNiG Oddział w Sanoku.

Breiman L., Friedman J.H. (1985) Estimating optimal transformations for multiple regression and correlation. Journal of the American Statistical Association (September): 580-598.

Caers J. (2005) Petroleum Geostatistics. Society of Petroleum Engineers.

Carman P.C. (1937) Fluid flow through granular beds. Transactions of the Institution of Chemical Engineers, 15: 150-167.

Chopra S., Marfurt K.J. (2005) Seismic attributes - a historical perspective. Geophysics, 70: 3SO-28SO.

Corbett P.W.M., Ellabard Y., Mohhammed K. (2003) Global hydraulic elements- elementary petrophysics for reduced reservoir modeling. EAGE 65th Conference and Exhibition. Stavanger, F-26.
Darabos E., Szucs P., Németh A. (2011) Application of the ACE algorithm on hydrogeological monitoring data from the Bükk Mountains. Acta Geodaetica et Geophysica Hungarica, 47: 256-270.

Deutsch C.V. (2002) Geostatistical reservoir modeling. Oxford University Press.

Ebanks W.J. (1987) Flow unit concept - integrated approach for engineering projects. Abstract presented June 8, during the roundtable sessions at the 1987. AAPG, Annual Convention Materials.

Geofizyka Kraków (2002) Opracowanie wyników badań sejsmicznych 2D temat: Z 2D (I etap) rok: 2002. Archiwum Spółki Geofizyka Kraków sp. z o.o.

Gunter G.W., Finneman J.M., Hartmann D.J., Miller J.D. (1997) Early determination of reservoir flow units using an integrated petrophysical method. Paper SPE 38679 prepared for presentation at the 1997 SPE Annual Technical Conference and Exhibition held in San Antonio, Texas, 5-8 October, 1997.

Jarzyna J., Ha Quang M. (2009) Hydraulic units differentiated in reservoir rock to facilitate permeability determinations for flow modeling in gas deposit (in Polish with English summary). Przeglad Geologiczny, 57: 996-1003.

Hart B. (2008) Stratigraphically significant attributes. The Leading Edge, 27: 320-324.

Ha Quang M. (2011) Integrated reservoir characterization for fluid flow modeling of the $\mathbf{Z}$ gas deposit at the Carpathian Foredeep. Ph.D. thesis, Main Library of AGH University of Science and Technology, Kraków, Poland.

Ha Quang M., Jarzyna J. (2010) Application of artificial neural networks for properties modeling using well logs and 2D seismics in the Carpathian Foredeep gas field. Prace Instytutu Nafty Gazu w Krakowie, 170: 209-212. 
Karnkowski P. (1999) Oil and gas deposits in Poland. Geosynoptics Society "GEOS”, Kraków, Poland.

Kolodziej S. Jr. (1980) Analysis of pore throat size and use of the Waxman-Smits equation to determine OOIP in Spindle Field, Colorado. Paper SPE, 9382.

Kozeny J. (1927) Über Kapillare Leitung des Wassers im Boden (Aufstieg, Versikerung und Anwendung auf die Bemasserung). Sitzungsberichte der Akademie der Wissenschaften in Wien, Mathematisch-naturwissenschaftliche Klasse, 136 (Ila): 271-306.

Krzywiec P. (2006) Geodynamic and tectonic control on evolution of foreland basins, with references to the Carpathian Foredeep Basin (in Polish with English summary). Przegląd Geologiczny, 54: 404-412.

Krzywiec P., Aleksandrowski P., Ryzner-Siupik B., Papiernik B., Siupik J., Mastalerz K., Wysocka A., Kasiński J. (2005) Geological structure and origin of the Miocene Ryszkowa Wola Horst (Sieniawa-Rudka area, eastern part of the Carpathian Foredeep Basin) - results of 3D seismic data interpretation (in Polish with English summary). Przegląd Geologiczny, 53: 656-663.

Krzywiec P., Wysocka P., Oszczypko N., Mastalerz K., Papiernik P., Wróbel G., Oszczypko-Clowes M., Aleksandrowski P., Madej K., Kijewska S. (2008) Evolution of the Miocene deposits of the Carpathian Foredeep in the vicinity of Rzeszów (the Sokołów-Smolarzyny 3D seismic survey area) (in Polish with English summary). Przegląd Geologiczny, 56: 232-244.

MacQueen J.B. (1967) Some methods for classification and analysis of multivariate observations. Proceedings of the 5th Berkeley Symposium on Mathematical Statistics and Probability, 1: 281-297.

Matyasik I., Myśliwiec M., Leśniak G., Such P. (2007) Relationship between hydrocarbon generation and reservoir development in the Carpathian Foreland. In: Thrust Belts and Foreland basins: from Fold Kinematics to Hydrocarbon Systems Lacombe (eds. O.J. Lave, F. Roure and J. Verges): 413-430. Springer-Verlag.

Michael K.N. (1999) A note on constrained k-means algorithms. Pattern Recognition, 33: 515-519.

Mikes D., Barzandji O.H.M., Bruining J., Geel C.R. (2006) Upscaling of small-scale heterogeneities to flow units for reservoir modeling. Marine and Petroleum Geology, 23: 931-942.

Mohammadlou M.H., Mork M.B. (2010) Integrated petrophysical analysis in tight and brecciated carbonate reservoir. Proceedings of the SPE Annual Technical Conference and Exhibition, Florence, Italy, 19-22 September, 2010.

Myśliwiec M. (2004a) The Miocene reservoir rocks of the Carpathian Foredeep (in Polish with English summary). Przegląd Geologiczny, 52: 581-592.

Myśliwiec M. (2004b) Exploration for gas accumulations in the Miocene deposits of the Carpathian Foredeep using Direct Hydrocarbon Indicators (southern Poland) (in Polish with English summary). Przegląd Geologiczny, 52: 299-306.

Myśliwiec M. (2006a) Types of the Miocene reservoir rocks (Żołynia-Leżajsk gas field) and the methods of the gas reserves estimation (in Polish with English summary). Nafta-Gaz, 62: 139-150.

Myśliwiec M. (2006b) Żołynia-Leżajsk - old gas fields, new reserves (in Polish with English summary). Nafta-Gaz, 62: 97-105.

Myśliwiec M., Madej K., Byś I. (2004) The Miocene gas fields discovered in the Rzeszow area, Carpathian Foredeep, on the base of the Direct Hydrocarbon Indicators (in Polish with English summary). Przegląd Geologiczny, 52: 501-506.

Oszczypko N. (1998) The Western Carpathian Foredeep - Development of the foreland basin in front of the accretionary wedge and its burial history (Poland). Geologica Carpathica, 49: 415-431.

Oszczypko N. (2006) Development of the Polish sector of the Carpathian Foredeep (in Polish with English summary). Przegląd Geologiczny, 54: 396-403.

Oszczypko N., Krzywiec P., Popadyuk I., Peryt T. (2006) Carpathian Foredeep Basin (Poland and Ukraine) - its sedimentary, structural and geodynamic evolution. AAPG Memoir, 84: 293-350.

Oszczypko N., Ślączka A., Żytko K. (2008) Tectonic subdivision of Poland: Polish Outer Carpathians and their Foredeep (in Polish with English summary). Przegląd Geologiczny, 56: 927-935.

Papiernik B., Górecki W., Pasternacki A. (2010) Preliminary results of 3D modeling of petrophysical parameters for tight gas prospecting in the Polish Rotliegend Basin (in Polish with English summary). Przegląd Geologiczny, 58: 352-364.

Pietsch K., Marzec P., Kobylarski M., Danek T., Leśniak A., Tatarata A., Gruszczyk E. (2007) Identification of seismic anomalies caused by gas saturation on the basis of theoretical $P$ and PS wavefield - Carpathian Foredeep, SE Poland. Acta Geophysica, 55: 191-205.

Porębski S. (1996) Principles of sequence stratigraphy in clastic sequences (in Polish with English summary). Przegląd Geologiczny, 44: 995-1006.

Prasad M. (2000) Velocity-permeability relations with hydraulic units. Geophysics, 68: 108-117.

Roksandić M. (2006) Seismic facies analysis concepts. Geophysical Prospecting, 26: 382-398.

Rushing J.A., Newsham K.E., Blasingame T.A. (2008) Rock typing - keys to understanding productivity in tight gas sands. Paper SPE: 114-164.

Shuguang M., Journel A.G. (1999) Conditional 3D simulation of lithofacies with 2D seismic data. Computer and Geosciences, 25: 845-862.

Suarez Y., Marfurt K.J. (2008) Seismic attribute-assisted interpretation of channel geometries and infill lithology: a case study of Anadarko Basin Red Fork Channels. 2008 SEG Annual Meeting, November 9-14, 2008, Las Vegas, Nevada.

Svirsky D., Ryazanov A., Panko M., Corbett P.W.N., Posysoyev A. (2004) Hydraulic flow units resolve reservoir description challenges in the Siberian oil fields. Paper SPE, 87056: 1-15.

Śmist P. (2003) Zmiany w litologiczno-facjalnym wykształceniu osadów miocenu w rejonie Z-Ch.D.-G.D. Archiwum PGNiG S.A. Jasło.

Varavur S., Shebl H., Salman S.M., Shibasaki T., Dabbouk C. (2005) Reservoir rock typing in a giant carbonate., SPE EUROPEC/EAGE Annual Conference and Exhibition, Southwest Kansas, October 2005, Paper SPE, 93477.

Ward J.H. (1963) Hierarchical grouping to optimize an objective function. Journal of the American Statistical Association, 58: 236-244.

Xue G., Datta-Gupta A., Valko P., Balsingame T. (1996) Optimal transformations for multiple regression: application to permeability estimation from well logs. Paper SPE, 35412 presented at the Improved Oil Recovery Symposium, Tulsa, 21 April 1996. 